Received Date : 09-Sep-2014

Revised Date : 26-Feb-2015

Accepted Date : 03-Mar-2015

Article type : Original Article

\title{
Climatic and halokinetic controls on alluvial-lacustrine sedimentation during compressional deformation, Andean forearc, northern Chile
}

\author{
Laura A. Evenstar ${ }^{1 *}$, Adrian J. Hartley ${ }^{1}$, Stuart G. Archer ${ }^{2}$ \& Joyce E. Neilson ${ }^{1}$ \\ ${ }^{1}$ Deptartment of Geology and Petroleum Geology, University of Aberdeen, Aberdeen, \\ AB24 3UE, UK \\ 2Dana Petroleum, 62 Huntly Street, Aberdeen, AB10 1RS, UK \\ *Corresponding author now at School of Earth Science, University of Bristol, Wills \\ Memorial Building, Queens Road, Bristol, BS8 1RJ, UK (l.evenstar@bristol.ac.uk)
}

Running Title; Climatic and halokinetic controls on sedimentation

\begin{abstract}
The Salar de Atacama forms one of a series of forearc basins developed along the western flank of the Central Andes. Exposed along the northwest margin of the basin, a salt-cored range, the Cordillera de la Sal, records the Mid-Miocene to recent sedimentological and structural development of this basin. Sediments of the Mid-Miocene Vilama Formation record the complex interaction between regional/local climate change, halokinesis and compressional deformation. This study reveals how these factors have controlled the facies development and distribution within the Salar de Atacama. Detailed sedimentary logging, cross sections and present day geomorphology through the northern Cordillera de la This article has been accepted for publication and undergone full peer review but has not been through the copyediting, typesetting, pagination and proofreading process, which may lead to differences between this version and the Version of Record. Please cite this article as doi: 10.1111/bre.12124

This article is protected by copyright. All rights reserved.
\end{abstract}


Sal have been used to establish a lithostratigraphy, chronostratigraphy and the regional distribution of the Vilama Formation. The Vilama Formation documents an increase in aridity with a hiatus in sedimentation from Mid-Miocene to $9 \mathrm{Ma}$ with initial uplift of the Cordillera de la Sal. From 9 Ma till 8.5 Ma deposition of a meandering fluvial system is recorded followed by a rapid decrease in sedimentation till 6 Ma. From 6 to 2 Ma the deposition of extensive palustrine carbonates and distal alluvial-mudflat-lacustrine demonstrates the existence of an extensive lake within the Salar de Atacama. Post 2 Ma the lake decreased in size and braided alluvial gravels associated with alluvial fans were widespread through the region suggesting a final shift to hyperarid conditions. By comparing the Vilama Formation with similar age facies throughout northern Chile and southern Peru, several shifts in climate are recognised. Climate signatures within northern Chile appear to be largely diachronous with the last regional event in the Mid-Miocene. Since that time humid events have been restricted to either Precordillerian basins or the Central Atacama. Within the Central Atacama the final switch to hyperarid conditions was not till the earliest Pleistocene, much later than previously estimated within the region.

\section{Introduction}

Climate change within the Atacama Desert, Regions 1 and 2 of northern Chile since the Oligocene-Miocene is a topic of significant debate. In particular, the timing of the switch to hyperaridity is hotly debated with a large age range based on numerous different proxies. Original research suggested a shift in climate at 14 Ma based on cessation of supergene enrichment and paleosurface development (e.g. Mortimer and Saric 1975, Sillitoe et al. 1968, Alpers and Brinhall 1988). While later research provided increasingly younger ages based on sedimentology (Hartley et al. 2005, Sáez et al. 2012, Jordan et al. 2014), new ages of supergene enrichment (Hartley and Rice 2005), biotaxa (Gayo et al. 2012), archaeology (Gayo et al 2012), geomorphology (Jordan et al. 2014), isotope records (Rech et al. 2010), cosmogenic nuclide dating of surfaces (Placzek et al. 2010) and paleosol characteristics (Rech et al. 2006). Current theories suggest the region became hyperarid within the Oligocene (Dunai et al. 2005), Mid Miocene (e.g. Alpers and

This article is protected by copyright. All rights reserved. 
Brinhall 1988, Rech et al. 2006) or Pliocene (Hartley, 2003; Hartley et al. 2005). While other authors have suggested numerous switch events between hyperarid and arid throughout the Miocene (Hartley and Chong 2002, Evenstar et al. 2009) and even short lived arid to semiarid events within the Pleistocene and Holocene (Placzek et al. 2010, Sáez et al. 2012, Gayo et al 2012 and Jordan et al. 2014) In order to better constrain the timing of regional shifts in the climate, the relationship between local and regional climate change and tectonics needs to be understood.

The Salar de Atacama forms one of a number of internally drained Pre-Andean basins developed on the western flank of the Andes (Fig. 1). It is the most easterly basin within the Central Depression of northern Chile and as such, studies of the basin-fill succession can provide a unique insight into how sedimentary systems have responded to climate signatures within the Atacama Desert. Current climate records within this region are based on either data from basins that are currently exorheicly-drained (e.g. Calama Basin and QuillaguaLlamara basin) or on broad, regional correlations, which may not necessarily be applicable to this region. The Salar de Atacama basin has been internally drained throughout the Cenozoic (Jordan et al. 2007) and therefore provides a unique insight into how climate change and tectonic activity have controlled sedimentation within the forearc since the Late Cenozoic.

Within this paper, we examine the relationship between the deposition of MioPliocene aged alluvial/fluvial/lacustrine sediments of the Vilama Formation that were deposited along the North-West flank of the Salar de Atacama basin, northern Chile during a period of salt movement induced by compressional tectonic activity. The Vilama Formation sediments are derived from the basin margin (Cordillera de Domeyko) to the northwest and were shed south eastwards across an emerging salt-cored range referred to as the Cordillera de la Sal. This paper provides new sedimentological evidence of how the local/regional climate change and halokinetic movement has controlled the deposition of facies from the Oligocene to present day within the Salar de 
Atacama Basin and allows constraints to be placed on the timing and nature of climate change during the Cenozoic in northern Chile.

\section{Regional Geological Setting}

The Salar de Atacama basin of northern Chile (Fig. 1) is enclosed to the east by the modern magmatic arc (the Western Cordillera), and to the west by an uplifted block of Mesozoic-Palaeogene basement rock (the Cordillera de Domeyko). Seismic studies show the basin to be infilled with over $8 \mathrm{~km}$ of continental sediments (Jordan et al. 2007). It forms one of a number of Pre-Andean basins located between the Precordilleran fault system, which forms part of the Precordillera to the west, and the modern magmatic arc to the east. Seismic and gravity studies of the underlying lithosphere show the region to be underlain by a colder, denser lithospheric block than surrounding regions (Schurr and Rietbrock, 2002, Reutter et al. 2006). This geophysical anomaly has been interpreted as creating an area of subsidence, infilled with large volume of sediment (Reutter et al. 2006).

The Salar de Atacama formed under a regional extensional regime during the early Jurassic-early Cretaceous (Macellari et al. 1991, Hartley et al. 1992, Flint et al. 1991, and Munoz et al. 2002) with later compressional conditions in the Late Cretaceous (Munoz et al. 1997, Arriagada et al. 2002, Mpodozis et al. 2005 and Jordan et al. 2007). Compression led to the uplift of the Cordillera de Domeyko, on the western edge of the basin, initially in the Late Cretaceous with a major phase of uplift in the Eocene (Arriagada et al. 2006, Jordan et al. 2007) and with continued uplift until the Miocene (Muñoz et al. 2002). The Cordillera de Domeyko forms a ridge running NNE to SSW with an average elevation of $3000 \mathrm{~m}$ (Fig. 1). The Cordillera de Domeyko forms a complexly deformed thrusted sequence of Jurassic to Eocene strata (Jolley et al. 1990). To the east, the Cordillera de Domeyko is bound by the Paciencia Fault. This fault has been interpreted as either a large displacement normal fault activated in the Oligocene (Pananont et al. 2004) or as an east verging thrust sheet (Jolley et al. 1990, Arriagada et al. 2002, Reutter et al. 2006). Between the Paciencia Fault and the Cordillera de la Sal is a small sub-basin $8 \mathrm{~km}$ wide (the Llano de Paciencia Basin) infilled with alluvial fans sourced from the Cordillera de la Domeyko (Jolley et al. 
1990). The Cordillera de la Sal forms a $7 \mathrm{~km}$ wide and $90 \mathrm{~km}$ long ridge of salt highs separating the Llano de Paciencia from the active saltpan of the Salar de Atacama to the east. To the south the Cordillera de la Sal decreases in width until $23^{\circ} 31^{\prime}$ where the Llano de Paciencia and Salar de Atacama merge to form a single basin. To the north the Cordillera de la Sal passes into the San Bartolo rhyolite dome (Hollingworth and Rutland, 1968, Jolley et al. 1990).

The Salar de Atacama has been a depositional basin since at least the Triassic with $4.5 \mathrm{~km}$ of sediment of the Purilactis Group being deposited within the Cretaceous (Jordan et al. 2007) (Fig. 2). During the Oligocene, the Paciencia Group was deposited in the Salar de Atacama. The Paciencia Group consists of the Tambores Formation, a package of alluvial conglomerates that interfingers with the San Pedro Formation, a series of fine-grained clastic sediments interbedded with halite layers (Fig. 2). The timing of sedimentation is constrained as initiating at $\sim 30 \mathrm{Ma}($ Kape, 1996) and continuing to the midMiocene (Kape, 1996, Jordan et al. 2007). The sequence varies in thickness from $400 \mathrm{~m}$ in the southwest of the Salar de Atacama to over $1800 \mathrm{~m}$ towards the Cordillera de la Sal due to variable subsidence within the basin (Jordan et al. 2007, Fig. 3). During the early to mid Miocene the Paciencia Group started to deform into a series of salt-cored folds along the axis of the present day Cordillera de la Sal to form a barrier to eastward sediment transport from the Cordillera Domeyko and initiating the formation of the Llano de Paciencia Basin (Jolley et al. 1990). Timing of salt movement within the Paciencia Group is based on the unconformity between the folded Paciencia Group and the Cerro Jorquencal lava dated at $17 \pm 2$ Ma (Ramírez, 1979) in the northeast of the basin and the regional unconformity between the folded Paciencia Group and Artola Ignimbrite dated at $9.40 \pm 0.03$ Ma within the northwest of the basin (Naranjo et al. 1994, Salisbury et al. 2010) (Fig. 2). Salt movement continued to uplift strata along this north-south trend until the Pliocene (Blanco et al. 2000).

Sedimentation within the Salar de Atacama basin region continued until the present day recording occasional less arid phases of mudflat and saline lake development within the Pleistocene and Holocene (Bobst et al. 2001, Quade et al. 2008).

This article is protected by copyright. All rights reserved. 
The trigger for the diapiric deformation of the Paciencia Group forming the Cordillera de la Sal is still unknown. Initial studies based on both field observations and seismic reflection data in the region suggest the Paciencia Fault between the Cordillera Domeyko and Llano de Paciencia forms part of a frontal thrust fault within the Cordillera de Domeyko that was active in the Late Eocene and again in the Upper Miocene (Jolley et al. 1990, Munoz et al. 2000, Ruetter et el. 2006) (Fig. 3a). During the Mid Miocene this thrust front propagated eastward to form the Cordillera de la Sal. The complex salt deformation formed over a series of thrust faults which linked back to the Paciencia thrust fault through a series of a shallow ramp structures (Jolley et al. 1990). The Llano de Paciencia formed as a "piggy back" basin developed on a thrust sheet while the Cordillera de la Sal formed a pop up structure with a minor east dipping back thrust propagating west (Jolley et al. 1990). Later work by Muñoz et al. (2002) based on seismic interpretation agreed with this but suggested the Cordillera de la Sal Frontal Thrust on the eastern edge of the Cordillera formed part of a basement involved thick skinned thrust fault. In contrast, later studies of seismic reflection data have suggested that the Cordillera de la Sal was generated by gravity upwelling of salt generated by reverse offset along the Tulor fault to the east of the Cordillera de la Sal through the Mid Miocene to Pliocene (Panamount et al. 2004 and Jordan et al. 2007) (Fig. 3b).

\section{Vilama Formation Overview}

The Vilama Formation (Fig. 2) was deposited in the north western area of the Salar de Atacama from the Late Miocene to Pliocene. The formation is constrained in age by a basal ignimbrite (the Artola ignimbrite) dated at $9.40 \pm$ $0.03 \mathrm{Ma}$ (Salisbury et al. 2010) and several ash layers in the upper parts dated at $3.7 \pm 1.0 \mathrm{Ma}$ (Blanco et al. 2000) and 2.0 $\pm 0.9 \mathrm{Ma}$ (Naranjo et al. 1994). Within the Llano de Paciencia the lower part of the formation consists of a series of ignimbrites interbedded with alluvial gravels. This was initially regarded as a separate group and termed the San Bartolo Group (Hollingworth and Rutland, 1968, Ramírez, 1979 and Flint, 1985) or Hollingworth gravels (fig. 2) (Naranjo et al. 1994), but subsequently reassigned to the lower part of the Vilama Formation (Marinovic and Lahsen, 1984, Wilkes and Gorler, 1994). These strata are

This article is protected by copyright. All rights reserved. 
recognised as the Lower Vilama Gravels (LVG) within this paper. Overlying the ignimbrites and gravels, the upper part of the Vilama Formation contains a series of fluvial conglomerates and sandstones interbedded with fluvial to lacustrine sandstones and saline lake carbonates (Blanco et al. 2000). Blanco et al. (2000) assigned these to 3 members (Fig. 2). Member 1 (oldest): a 35 m thick sequence of grey carbonate cemented trough cross-stratified sandstones, pebbly sandstones, mudstones and tuffs interpreted as alluvial fan into ephemeral lake deposits; Member 2: a 30 m thick sequence of finely laminated red siltstones, tuff rich sandstones with occasional thin conglomerates showing bioturbation and soft sediment deformation structures interpreted as delta plain, delta front and shallow lacustrine; Member 3 (youngest): a $13 \mathrm{~m}$ thick sequence of dark grey to reddish grey trough stratified beds of alluvial gravels with occasional beds of sandstone and red mudstone interpreted as delta/lake environments. East of the Cordillera de la Sal, the Vilama Formation increases in thickness to $>1000 \mathrm{~m}$ and consists mainly of halite (Jordan et al. 2007). This paper focuses on the sedimentology of the Vilama Formation; its regional distribution and relationship with salt related structures in the northern part of the Cordillera de la Sal. In addition we analyse local and regional climatic controls on Vilama Formation deposition and discuss these within the context of climate change along the western flank of the Central Andes.

\section{Methodology and Data Set}

New sedimentological data have been acquired through sedimentary logging (at a scale of 1:25), of nine sections within the Cordillera de la Sal. These were used to construct a general lithostratigraphy for the Vilama Formation.

Lithostratigraphic units identified through logging, were mapped throughout the northwestern area of the Cordillera de la Sal (Fig. 4). Three northwest to southeast cross sections through the Cordillera de la Sal were constructed (Fig. 4). Field observations combined with mapping of the Vilama Formation and present day geomorphology were integrated with previously published stratigraphy and map information to create a 3D model for the evolution of the Cordillera de la Sal from the Mid-Miocene to the present day.

This article is protected by copyright. All rights reserved. 


\section{Sedimentary Facies Associations}

The Vilama Formation contains six facies associations within the Cordillera de la Sal region. These are the: volcaniclastic, meandering fluvial, distal alluvial fan, distal alluvial-mudflat-lacustrine, distal alluvial-lacustrine, and palustrine carbonate. A summary of the sedimentary facies that occur within each facies association can be seen in Tables 1 and 2. A key for subsequent logs is shown in Figure 5. A brief description of each association is given below.

\subsection{Volcaniclastic Facies Association (Salar de Atacama Ignimbrites)}

\subsubsection{Description}

Three extensive ignimbrite units are recognised throughout the study area: Artola, Sifon and Pelon ignimbrites as well as a series of smaller discontinuous ignimbrite layers and ash flows. They occur as sheet like bodies and vary in thickness from $5 \mathrm{~cm}$ up to $10 \mathrm{~m}$. They are generally unwelded, have a massive crystal-rich (mainly biotite mica) structure, and vary in colour from white to pink to green.

The Artola and Sifon ignimbrites only outcrop on the western part of the Cordillera de la Sal field area. The Artola ignimbrite has a thickness of $\sim 6 \mathrm{~m}$ and is salmon-pink colour with a high biotite content. Stratigraphically higher, the Sifon Ignimbrite has a thickness of $\sim 7.5 \mathrm{~m}$ and is a white-pink colour. The Pelon is the stratigraphically highest ignimbrite and is up to $10 \mathrm{~m}$ thick in the west of the Cordillera de la Sal and is the most prevalent of the ignimbrites outcropping throughout the study area. This ignimbrite displays a green-white-pink colouration and is crystal rich. The ignimbrites are formed from pyroclastic flows from the east and northeast of the Salar de Atacama (Gardeweg and Ramírez, 1987) and have been dated radiometrically by Salisbury et al. (2010) at $9.40 \pm 0.03 \mathrm{Ma}$ (Artola Ignimbrite), $8.33 \pm 0.06 \mathrm{Ma}$ (Sifon Ignimbrite) and $5.82 \pm$ $0.08 \mathrm{Ma}$ (Pelon Ignimbrite). The ignimbrites were identified individually within the field by colour, thickness, crystal to matrix ratio and biotite content using the descriptions provide by De Silva (1989), and the stratigraphic relationships

This article is protected by copyright. All rights reserved. 
between individual ignimbrite flows (Jolley et al. 1990, Naranjo et al. 1994, Blanco et al. 2000), and their relationships to the underlying San Pedro Formation and overlying Vilama Formation (Jolley et al. 1990, Naranjo et al. 1994, Wilkes and Gorler, 1994, Blanco et al. 2000).

Above the ignimbrites, thin volcaniclastic beds are interbedded with the distal alluvial-mudflat-lacustrine and distal alluvial-lacustrine facies (described below). They form thinly bedded units up to $2.5 \mathrm{~m}$ thick of either ignimbrite or ash that are occasionally reworked by fluvial or lacustrine processes. Two of the ash layers have been dated at 3.7 $\pm 1.0 \mathrm{Ma}$ (Blanco et al. 2000) and 2.0 $\pm 0.9 \mathrm{Ma}$ (Naranjo et al. 1994).

\section{2 Meandering Fluvial Facies Association}

\subsubsection{Description}

This facies type is up to $26 \mathrm{~m}$ thick at the base of the Vilama sedimentary units and only outcrops on the north western edge of the Cordillera de la Sal. A description of the facies in shown in Tables 1 and 2. A summary log and field photo can be seen in Fig. 6. The unit is comprised of a series of single storey asymmetrical channels (30 to $110 \mathrm{~cm}$ thick) infilled with pebble to boulder grade conglomerates that cut into the sheet sandstones and mudstone facies. Channel fills are predominately cross bedded and occasionally massive. Within the channels the margins are created by packages of inclined beds parallel to the cut bank interpreted as lateral accretion units. The channel fill shows packages of upward grading from conglomerates to sandstones increasingly composed of the underlying units (San Pedro formation and Artola ignimbrite). The sheet sandstones and mudstones that host the channels show predominantly planar lamination to tabular cross bedding and trough cross bedding and fine upwards from medium grade sandstone to siltstone varying in thickness up to $1.6 \mathrm{~m}$. The entire unit shows a general coarsening upward towards the top of the facies. Paleocurrent directions measured from clast imbrication show a flow direction predominately to the north.

\subsubsection{Interpretation}

This article is protected by copyright. All rights reserved. 
The lateral accretion packages which represent point bar deposits, combined with the channel geometry and erosive contacts with the underlying units indicate deposition in meandering fluvial channels. The trough cross stratification and imbricated conglomerates were deposited in high-energy conditions as part of channel bar forms. The decrease in clast size towards the top of some of the units indicate decreasing flow regime either due to a waning of the flow, gradual lateral accretion or abrupt channel switching. The sheet-like nature, cross bedding and planar lamination and absence of primary current lineation in the sandstone indicate the sand was deposited under low-flow conditions in unchannelised to poorly confined channels. The fining upwards nature of the sandstone bodies over a 5 to $80 \mathrm{~cm}$ scale indicates waning flow followed in some cases by silt/mud deposition from suspension in standing bodies of water from a single flow event. The sheet sandstone and mudstone facies are interpreted as predominately overbank deposits with occasional deposition in the main channel from waning flow conditions.

Within the Vilama Formation this facies is informally named the Lower Vilama Gravels (LVG). The entire unit is interpreted as a meandering fluvial system. Meandering channels sit within overbank sandstone to mudstone environments. The general coarsening upward nature of the facies overall suggests progradation of the channel towards the top of the formation.

\subsection{Distal Alluvial Fan Facies Association}

\subsubsection{Description}

This facies is composed of a series of amalgamated, stacked channel-fill packages of conglomerates, sandstones and mudstones with individual channels up to 150 $\mathrm{cm}$ thick and amalgamated packages up to $300 \mathrm{~cm}$ thick. The channels vary in width from $40 \mathrm{~cm}$ to $300 \mathrm{~cm}$ across. The erosional base of channel packages cuts up to $50 \mathrm{~cm}$ into underlying sediments and is overlain by reworked ripped up clasts of underlying siltstone and mudstone. Sandstones and conglomerates within the channels show tabular cross lamination, trough cross bedding and climbing ripples. The channel-fill units mainly comprise conglomerates and trough cross-bedded sandstones with cross laminated sandstones and

This article is protected by copyright. All rights reserved. 
mudstones/siltstones only occasionally preserved. Paleocurrent directions measured from imbricated clasts show a predominant flow direction towards the southeast.

\subsubsection{Interpretation}

The amalgamated, multistorey channels with erosional bases are interpreted as braided-river deposits. This unit differs from the meandering facies due to the lack of lateral accretion surfaces and absence of sheet sandstone or mudstones. The trough cross stratified and imbricated conglomerates were deposited in high-energy conditions as part of channel bar forms, with the fining upwards in clast size indicating decreasing flow regime as the channel shifted or flow events wane. The stacking of the erosional channels indicated a braided fluvial system similar to the confined part of a distal alluvial fan as described within the Llano de Paciencia by Jolley et al. (1990). Within the Vilama Formation, this facies is informally called the Upper Vilama Gravels (UVG).

\subsection{Distal alluvial-mudflat-lacustrine Facies Association}

\subsubsection{Description}

This unit contains a series of interbedded sheetlike bodies of gravel/sand, mud and diatomite with occasional volcanic deposits. A summary log of the sequence is shown in Fig. 7 and is described in Tables 1 and 2.

The sheet sandstones vary in thickness between 5 and $310 \mathrm{~cm}$ and are laterally continuous within the exposure $(>75 \mathrm{~m})$ with most showing a fining upwards trend from rip-up clasts of underlying material at their base to predominantly red to brown mudstone/siltstone and diatomite at the top. Beds are generally massive with occasional thin beds of cross lamination and climbing ripples. The sandstone beds are interbedded with sheet mudstones/siltstones that are finely laminated. Diatomite beds vary in thickness from 12 to $300 \mathrm{~cm}$ and occasionally contain diagenetic nodular chert and calcite cemented horizons.

The facies displays a number of fining upwards cycles from homogenous sheet sandstone up to mudstone to fine diatomite and siliceous mudstone. The base of

This article is protected by copyright. All rights reserved. 
each cycle is represented by a 3 to $10 \mathrm{~cm}$ unit of conglomerates and coarse sandstone, which is mainly massive with occasional cross stratification. This is overlain by medium to coarse sandstone with occasional cross stratification. The top of each cycle is represented by a thin silt-clay and/or diatomite bed. The entire cycle varies in thickness from $0.5 \mathrm{~m}$ to $6 \mathrm{~m}$. Occasional volcanic inputs of ignimbrites or ashes are also recorded within the unit that may be reworked by lacustrine processes.

\subsubsection{Interpretation}

The cyclic nature of the deposits combined with the sheet like geometries and the fining upwards character indicate periodic high-energy flood events. Deposition occurred during waning flow conditions and the association with lacustrine diatomites suggests deposition from a density flow entering an ephemeral body of water at the terminal lobes of an alluvial/fluvial fan. The finegrained cross-laminated sandstones and the overlying sheet sandstone deposits represent the waning of the density flow with the clay-siltstones representing suspension dropout.

Diatomites form from the concentration of unicellular aquatic diatoms formed in lacustrine or marine conditions. They are formed from benthic and planktonic microfossils that are largely associated with volcanic deposits from which the silica originates with hydrothermal activity associated with silica mobility. The generally massive, horizontally continuous bedding of diatomite and siliceous mud indicate low energy conditions of a continental lake environment.

The whole sequence is interpreted to record pulses of alluvial/fluvial sediments associated with progradation of an alluvial/fluvial fan or switching of alluvial/fluvial lobes into a lacustrine environment. They are similar to the lacustrine facies described in the Calama Basin (May et al. 1999) and Quillagua-Llamara Basin (Sáez et al. 1999). Within the Vilama Formation this facies is informally called the Vilama Redbeds (VR).

\subsection{Distal alluvial-lacustrine Facies Association}

This article is protected by copyright. All rights reserved. 


\subsubsection{Description}

This unit is similar to the distal alluvial-lacustrine-mudflat facies association comprising a series of interbedded sheetlike bodies of gravel/sand fining upwards to mud and diatomite with occasional reworked volcanic deposits. However the muds within this unit are grey, black and green interbedded with fine to coarse sand. The unit is described in Tables 1 and 2 .

The sheet sands to gravel beds vary in thickness between $5 \mathrm{~cm}$ to $50 \mathrm{~cm}$ but are predominately 5-10 cm thick. The beds are planar based and laterally continuous within the sections. The sandstones show thin beds $(10 \mathrm{~cm}$ to $30 \mathrm{~cm})$ of tabular cross lamination and climbing ripple sets and are interbedded with fine beds of grey, black and green siltstone and mudstone. The mudstone beds are between $<1 \mathrm{~cm}$ and $100 \mathrm{~cm}$ thick. The facies shows several fining up sequences from sandstone to mudstone and diatomite on the scale of $20-50 \mathrm{~cm}$ with abundant soft sediment deformation within the basal 3 meters of the facies association.

The facies association shows a general fining upwards over 20 to 30 meters. The basal 4 meters contains fining upward sequences of gravels to interbedded sheet sands and muds with soft sediment deformation. Overlying this, the facies is increasingly dominated by small fining up sequences of interbedded mudstones and sandstone with occasional diatomite units. Towards the top of this facies association diatomites become the predominant facies type.

\subsubsection{Interpretation}

The basal part of this facies is similar to the distal alluvial-mudflat-lacustrine facies with the cyclic nature of the deposits associated with a turbidity current type transport and deposition of sediments supplied from the terminal lobes of an alluvial/fluvial fan into a shallow water body. However the absence of red or brown mudstones combined with the abundance of soft sedimentary deformation features indicates a distal alluvial-lacustrine facies with no subaerial exposure. The decrease in clast size and increase in diatomite towards the top of the facies indicates decreasing fluvial input into a continental lake

This article is protected by copyright. All rights reserved. 
environment through time. The sequence is similar to those described in the Calama Basin (May et al. 1999) and Quillagua-Llamara Basin (Sáez et al. 1999). Within the Vilama Formation this facies is informally called the Vilama Minibasin Mudstones (MVM).

\subsection{Palustrine Carbonate Facies Association}

\subsubsection{Description}

Located only on the north-eastern side of the Cordillera de la Sal, the entire facies association thickness is $15 \mathrm{~m}$. A summary log is shown in Figure 8 and described in Tables 1 and 2. The unit contains a series of thick (up to $2 \mathrm{~m}$ ) travertine beds regularly interbedded, typically at $1 \mathrm{~m}$ intervals, with thinner $(\sim 20 \mathrm{~cm})$ stromatolite and clastic limestone deposits. Beds are laterally extensive within the section (over 6 meters). The travertine forms vertical calcareous tubes between 1 to $10 \mathrm{~cm}$ in length are fringed by sparry calcite (Fig 9a). The vertical tubes form small layers intercalated with horizontally laminated beds ( 20 to $50 \mathrm{~cm}$ ) of limestone, which contains occasional ostracodes (Fig 9). The limestone varies from bioclastic wackestones - packstones with ostracods to algal grainstones-packstone with oncolites. Stromatolite beds show algal domal to laminate structures often overlain by coarse bioclastic grainstones (Fig. $9 \mathrm{~b}$ and $\mathrm{c}$ ).

Intercalated beds of clastic limestone vary in thickness between 20 to $50 \mathrm{~cm}$. Some beds show coarsening upward from medium sand to granular. The base of beds contains rip-up clasts of underlying carbonates and have increasing clastic content towards the top. Sedimentary structures are generally wavy lamination with occasional cross bedding $(10 \mathrm{~cm})$. Some of the section shows diagenesis with dolomitisation as well as silica replacement of some of the layers.

\subsubsection{Interpretation}

The travertine beds are a type of microbialite which forms near geothermal springs and are often linked to siliceous systems associated with volcanic activity. The tube-like structures of the travertine develop around plant material 
in close proximity to geothermal hot springs. At the present day $5 \mathrm{~km}$ to the north of San Pedro de Atacama, the Puritama hot springs has similar deposits. The stromatolite beds form as mud mounds in shallow waters by the trapping and bonding of sediments by microbial mats mainly composed of cyanobacteria (Tucker, 2011). Both the stromatolites and travertine growth indicates shallow carbonate-rich lake conditions. Oncolites within the grainstone, packstone and wackstone are also indicative of shallow (within the photic zone) warm water conditions.

The preservation of both the travertine and stromatolites indicates a low-energy shallow, lake environment. The thin beds of the more clastic packstone and wackstone interbedded with the travertine are interpreted as occasional storm deposits washed over the algal mats. Early diagenesis is likely to have occurred shortly after sedimentation as the dolomite is fine-grained and preserves the original structure of the stromatolites and travertine. Within the Vilama Formation this facies is informally called the Vilama Carbonates (VC).

\section{Post-sedimentation Diagenesis}

Within the Vilama Formation a regionally extensive, hard diagenetic layer is found to modify the underlying sedimentary layers. This layer provides a prominent horizon and is described below.

\subsection{Description}

This unit varies in thickness from 1 to $10 \mathrm{~m}$ and contains silcretised gravels, sandstones and mudstones. It usually preserves the original sedimentary structures of the units. It is found predominately as a modifier to the braided fluvial fan facies except in two locations where it modifies the distal alluvial-lacustrine diatomite facies.

\subsection{Interpretation}

The unit is interpreted as a silcrete with the preservation of the primary sedimentary structures being characteristic of groundwater silcretes (Thiry et al. 2006). Groundwater silcretes usually occur in response to a rise in water table associated

This article is protected by copyright. All rights reserved. 
with generally more humid periods (Thiry et al. 2006). The silcretes form from silica rich groundwater that could originate from hydrothermal activity which facilitates the dissolution of the silica and is associated with volcanic activity in the region. The groundwater silcrete in this region is interpreted as diagenetic in origin, recording a period of high water table or paleo-water table surface forming at a similar time to deposition to the Upper Vilama Gravels. The development of the groundwater silcrete is most likely related to variations in uplift and erosion associated with the active salt structures. At the time of diagenesis a number of areas had become uplifted and eroded so its presence in other units apart from the Upper Vilama Gravels, is taken to represent the location of the paleo-water table at this time.

\section{Facies Distribution of the Vilama Formation.}

The Vilama sediments vary in thickness across the area from $>100 \mathrm{~m}$ on the northwest thinning to $<3 \mathrm{~m}$ over the Valle de la Muerte Fault (labelled VDM in Fig. 12) before thickening back to $>100 \mathrm{~m}$ on the southeast side of the range. In several areas of the Cordillera de la Sal the Vilama Formation is completely eroded exposing the underlying San Pedro Formation.

The 9 sedimentary logs taken across the region highlight the general distribution of lithologies and correlation of the facies and are shown in Figure 10. Figure 11 highlights the chronostratigraphic relationship of the Vilama Formation sediments from the Llano de Paciencia to the Salar de Atacama. Three northwest to southeast cross sections (Fig. 12) have been constructed across the Cordillera de la Sal focused on the regional distribution of the Vilama Formation. These are based on field observations, facies changes, and unconformities and compiled using Landsat imagery and previous published map information (Dingman 1965, Wilkes and Görler 1988)

\subsection{Cross Section 1 (Fig. 12a)}

The northernmost cross section runs $8 \mathrm{~km}$ along the southern edge of the North Dome running from the northwest to southeast. Along the western edge of the Cordillera de la Sal, the base of the Vilama Formation is the Artola Ignimbrite ( $6 \mathrm{~m}$ 
thick) , which unconformably overlies the Paciencia Group and is dated at $9.40 \pm 0.03$ Ma (Salisbury et al. 2010). The Artola Ignimbrite is overlain by $26 \mathrm{~m}$ of the meandering fluvial facies termed the Lower Vilama Gravels. The Lower Vilama Gravels coarsen upwards and have a mean flow direction to the northwest. Overlying the Lower Vilama is the Sifon ignimbrite ( $7.5 \mathrm{~m}$ thick) dated at $8.33 \pm 0.03$ Ma (Salisbury et al. 2010), this is overlain by a thin layer $(<2 \mathrm{~m})$ made up of dolomitised palustrine carbonate facies association.

The Pelon Ignimbrite (dated at 5.82 $\pm 0.08 \mathrm{Ma}$ (Salisbury et al. 2010)) overlies the thin palustrine carbonate with a thickness of $10 \mathrm{~m}$ on the western edge of the Cordillera de la Sal. Overlying the Pelon ignimbrite is $24 \mathrm{~m}$ of Vilama Carbonate beds. The Vilama Carbonates grade into a $19 \mathrm{~m}$ thick package of Vilama Redbeds. Unconformably overlying the Vilama Redbeds is a layer of the Upper Vilama Gravels (thickness up to $25 \mathrm{~m}$ ). The gravels show a paleocurrent direction from northwest to southeast. These gravels are considered to be equivalent to Member 3 of Blanco et al. (2000). The basal $2 \mathrm{~m}$ of the Upper Vilama Gravels is silcretised.

Running east from the western edge of the Cordillera de la Sal the Lower Vilama Gravels ( $\sim 25 \mathrm{~m})$, Artola ( $\sim \mathrm{m})$, Sifon ( 7.5 m) and Pelon ( $\sim 10 \mathrm{~m})$ ignimbrite, Vilama Carbonates ( $24 \mathrm{~m}$ ) and Vilama Redbeds ( 19 $\mathrm{m}$ ) all thin and pinch out completely proximal to the Eastern Frontal Thrust . The groundwater silcrete within the Upper Vilama Gravels ( $2 \mathrm{~m}$ ) and a thin (1-10 m) layer of Upper Vilama Gravels thin towards the fault but continue to overlie it decreasing in thickness to 2-3 $\mathrm{m}$ and 3-4 $\mathrm{m}$ respectively. Between the Eastern Frontal Thrust and the Valle de la Muerte, two thrust faults ( 2 and 3 ) can be seen deforming the groundwater silcrete (Fig. 13a) and divide the area into 3 sub-basins. The Upper Vilama Gravels overlie theses faults showing deformation by syntectonic infilling of the basins with an increase in thickness up to $20 \mathrm{~m}$ towards the northwestern edge of the sub-basins. Within the southeastern basins, the silica-cemented Upper Vilama Gravels are underlain by the Pelon ignimbrite, which thickens towards the southeast.

The western side of the Valle de la Muerte is defined by a west dipping thrust fault. Within the valley, only the Paciencia Group outcrops forming a series of salt

This article is protected by copyright. All rights reserved. 
anticlines and synclines (Fig. 13 a). The Cordillera de la Sal Primary Frontal Thrust forms the eastern edge of the Valle de la Muerte and the western edge of the Cordillera de la Sal. The Cordillera de la Sal Primary Frontal Thrust forms a ridge of the Upper Vilama Gravels ( $23 \mathrm{~m}$ ) that overlie the Vilama Redbeds (>50 m). The Vilama Redbeds most likely represents Member 2 of Blanco et al. (2000) and along the eastern edge of the Cordillera de la Sal a single ash horizon gives an age of $2.0 \pm$ 0.9 Ma for the facies (Naranjo et al. 1994).

It is likely that the regionally extensive Pelon, Sifon and Artola ignimbrites all underlie this region to the east of the fault, however, there is no outcrop to confirm this. The Vilama Redbeds and Upper Vilama Gravels both show syntectonic growth and increase rapidly in thickness away from the frontal thrust into the Salar de Atacama basin. The Upper Vilama Gravels are likely to change laterally into the Vilama Redbeds towards the centre of the Salar de Atacama recording an overall downstream fining in more distal parts of the basin.

\subsection{Cross section 2}

Cross-section 2 is $11 \mathrm{~km}$ in length and runs northwest to southeast. From the Llano de Paciencia, the Paciencia Group forms a shallow salt-cored anticline, termed the central salt dome that terminates at Fault 3. The Artola Ignimbrite ( $6 \mathrm{~m})$, Lower Vilama Gravels ( $\sim 25 \mathrm{~m}$ ), Sifon Ignimbrite ( 7 $\mathrm{m})$, Pelon ignimbrite ( $\sim 10 \mathrm{~m})$ and Vilama Carbonates $(\sim 2 \mathrm{~m})$ thin and pinch out onto the side of the salt diapir. The Vilama Redbeds ( $\sim 24 \mathrm{~m})$, groundwater silcrete within Upper Vilama Gravels ( $\sim 5 \mathrm{~m})$ and Upper Vilama Gravels ( 7 $\mathrm{m}$ ) thin but continue over the salt anticline to Fault 3. Between Fault 3 and the edge of Valle de la Muerte a small sub-basin is formed. Within the central part of this basin, a thin (1-3 m) pod of Pelon Ignimbrite underlies the silica-cemented Upper Vilama Gravels. Between the edge of the Valle de la Muerte, formed by the west dipping thrust fault, and the Cordillera de la Sal Primary Frontal Thrust a series of small anticlines and synclines formed at a number of different times.

This article is protected by copyright. All rights reserved. 
Two minibasins are recognised that cut into the underlying Pelon Ignimbrite and San Pedro Formation. Minibasin 1 (labelled MB1 in Fig. 12) is at least $0.5 \mathrm{~km}$ by $0.5 \mathrm{~km}$ although the exact size is difficult to determine due to erosion to the north and burial to the south. The basin is infilled with $15 \mathrm{~m}$ of Vilama Minibasin Mudstones and $14 \mathrm{~m}$ of Vilama Redbeds with the basal $2 \mathrm{~m}$ of Vilama Redbeds represented by the groundwater silcrete. Minibasin 2 (labelled MB2 in Fig. 12) is $0.2 \mathrm{~km}$ wide with unknown length and is infilled with $22 \mathrm{~m}$ of Vilama Minibasin Mudstones, $24 \mathrm{~m}$ of Vilama Redbeds and $2 \mathrm{~m}$ of Upper Vilama Gravels, the basal $2 \mathrm{~m}$ of the Vilama Redbeds is silcretised with the groundwater silcrete, The Vilama Minibasin Mudstones within these basins contain ash beds that have been dated at $3.7 \pm 1.0$ Ma (Blanco et al. 2000) and represent Member 1 of Blanco et al. (2000). The Pelon ignimbrite and ash layer place the age of these basins as forming between $5.82 \pm$ $0.08 \mathrm{Ma}$ and $3.7 \pm 1.0 \mathrm{Ma}$. The sediments are seen to infill paleotopography created by movement of the underlying Paciencia salt. The basins show subsequent deformation, most obviously in minibasin 2 (Fig. 13b) with later halokenesis deforming the Vilama Formation.

Between Minibasin 2 and the Cordillera de la Sal Primary Frontal Thrust is a zone where only the Pacienica Group is exposed. To the east of the Cordillera de la Sal Frontal Thrust the Upper Vilama Gravels ( $23 \mathrm{~m}$ ) and Vilama Redbeds (> $50 \mathrm{~m}$ ) thicken rapidly off to the east into the active saltpan. As suggested above, it is likely that the 3 regional ignimbrites underlie this area.

\subsection{Cross section 3}

The most southerly cross section runs for $11 \mathrm{~km}$. On the north-western side the Vilama Formation, except part of the silcretised Upper Vilama Gravels, thin and pinch out onto the central salt dome. The silcretised Upper Vilama Gravels thins to 2 to $3 \mathrm{~m}$ between the south dome and the Valle de la Muerte Thrust Fault, a thin (3-5 $\mathrm{m}$ ) deposit of the Pelon ignimbrite underlies the succession. Overlying the silcretised Upper Vilama Gravels up to $10 \mathrm{~m}$ of Upper Vilama Gravels can be seen outcropping from the centre of the syncline to the Valle de la Muerte Thrust Fault. To the east of

This article is protected by copyright. All rights reserved. 
this, the cross section shows the same minibasins described above in cross section 2.

\section{Oligocene to Pleistocene Tectono-Sedimentary Evolution of the}

\section{Cordillera de la Sal Basin.}

\subsection{Paciencia Group (30 Ma - 9.5 Ma)}

The Paciencia Group was deposited during the Oligocene to early Miocene (Fig 14 A). The Cordillera de Domeyko which lies to the west was the main sedimentary source for a series of thick alluvial fans, termed the Tambores Formation (Marinovic and Lahsen, 1984; Flint et al. 1991; Kape, 1996). Towards the central parts of the Salar de Atacama basin, the Tambores Formation interfingered with fine grained clastic and halite layers of the active saltpan deposits termed the San Pedro Formation (Marinovic and Lahsen, 1984; Flint et al. 1991; Kape, 1996).

During the early Miocene the Paciencia Group started to deform along the current axis of the Cordillera de la Sal forming an unconformity between the Paciencia Group and the overlying Cerro Jorquencal lava (17 $\pm 2 \mathrm{Ma}$ ) (Ramírez, 1979). The area continued to be a focus of active uplift and erosion until deposition of the Artola Ignimbrite at $9.40 \pm 0.03$ Ma (Salisbury et al. 2010) (Fig $14 \mathrm{~B})$.

\subsection{Artola Ignimbrite and Lower Vilama Gravels (9.5 Ma - $8 \mathrm{Ma}$ )}

During the Middle to Late Miocene the Cordillera de Sal continued to uplift forming a single salt wall that incorporated the North Dome, Central Dome and South Dome on the western edge of the Cordillera de la Sal (Fig. 14 C). At this time the Cordillera de la Sal became a barrier to transport of sediments from the Cordillera de Domeyko. This combined with salt evacuation within the Llano de Paciencia created accommodation space for the sediment accumulation of the Lower Vilama Gravels. Paleocurrents from the base of the Lower Vilama Gravels show the sediments being channelled primarily to the north along the Llano de Paciencia paleo-valley. 
In the upper parts of the Lower Vilama Gravels the Cordillera de la Sal continued to uplift and became the main sedimentary source for the Lower Vilama Gravels in the Llano de Paciencia. The upward coarsening sequence is suggestive of the source area becoming more proximal or the climate becoming wetter. The clasts are increasingly composed of reworked Artola ignimbrite and Paciencia Formation material.

\subsection{Sifon Ignimbrite ( $8 \mathrm{Ma}$ )}

The Lower Vilama Gravels terminates with deposition of the Sifon Ignimbrite at 8.33 ( $\pm 0.06 \mathrm{Ma}$ ) (Fig. 14 D). Regionally extensive ignimbrite that infilled the topography in the Llano de Paciencia and Salar de Atacama and draped the sides of the salt wall within the western Cordillera de la Sal. The infilling of the topography caused a reduction in sediment supply due to burial and onlapping within the source area.

\subsection{Pelon Ignimbrite and Lake Development (8 $\mathrm{Ma}-3.5 \mathrm{Ma}$ )}

Following emplacement of the Sifon Ignimbrite, a period of hyperarid conditions lead to a hiatus in sedimentation from 8 Ma to $\sim 6 \mathrm{Ma}$. This was followed by more humid conditions within the Llano de Paciencia with development of a carbonate-rich lake forming the basal $2 \mathrm{~m}$ of the Vilama Carbonates on the northwest edge of the Cordillera de la Sal. Sedimentation was temporarily interrupted with deposition of the Pelon ignimbrite at $5.82( \pm 0.08 \mathrm{Ma})$. The regionally extensive Pelon Ignimbrite blanketed the entire Llano de Paciencia, Cordillera de la Sal and Salar de Atacama region (Fig. 14 E). The regional extent of the ignimbrite within the Cordillera de la Sal compared to the volumetrically larger Sifon ignimbrites (believed to exceed $1000 \mathrm{~km}^{3}$ (Salisbury et al. 2010) may partly be due to the infilling of previous topography by the Sifon ignimbrite producing a subdued topography prior to Pelon emplacement. It is also possible that the ignimbrite originated from a more proximal source area. Shortly after deposition of the Pelon ignimbrite sedimentation of the Vilama Carbonates resumed on the northwestern edge of the Cordillera de la Sal (Fig. 14 F). 
A period of uplift occurred after this in the Cordillera de la Sal, with a series of northeast to southwest linear features formed. Along the western edge of the Cordillera, the salt wall continued to uplift while along the eastern edge smaller anticlines and synclines formed in response to salt tectonics (Fig. 14 F). The uplifted regions were eroded resulting in erosional remnants of the Pelon Ignimbrite in the central part of the Cordillera de la Sal and between the eastern minibasins.

Along the eastern edge of the Cordillera de la Sal the small (1 km x $0.5 \mathrm{~km})$ minibasins created by salt movement were infilled by the Vilama Minibasin Mudstones containing an ash deposit dated at $3.7 \pm 1.0 \mathrm{Ma}$ (Blanco et al. 2000).

\subsection{Distal alluvial fans, mudflats and lakes (3.5 Ma-2 Ma)}

In the Middle Pliocene the Central Dome on the western ridge of the Cordillera de la Sal, a previous area of high topography started to subside, creating a minibasin. Distal alluvial fans started to aggrade over the Cordillera de la Sal interbedded with mudflat and lacustrine sediments (Fig. $14 \mathrm{G}$ ). The Vilama Redbeds were deposited, with the greatest thicknesses along the eastern and western edge of the Cordillera de la Sal and within the salt dissolution feature (Central Dome). Occasional volcanic ash layers are recorded at this time interbedded with lacustrine and mudflat sediments dating deposition of the lake sediments to $2.0 \pm 0.9 \mathrm{Ma}$ (Naranjo et al. 1994).

\subsection{Upper Vilama Gravels to Present Day (<2 Ma)}

Towards the end of the Pliocene increasingly hyperarid conditions resulted in lake desiccation with lacustrine sediments being replaced with the braided fluvial fans of the Upper Vilama Gravels sourced from the Cordillera de Domeyko (Fig. $14 \mathrm{H}$ ). The alluvial fan deposition occurred across the Llano de Paciencia and the Cordillera de la Sal. The salt dissolution feature the Central Dome between the North Dome and South Dome provided a sediment fairway for the alluvial sediments to cross the Cordillera de la Sal into the Salar de Atacama. Paleocurrent directions from the Upper Vilama Gravels show a flow

This article is protected by copyright. All rights reserved. 
predominantly to the North West over the region. This suggests that the Cordillera was partially aggraded over by the Upper gravels. Further to the north and south of the salt dissolution feature, the Upper Vilama Gravels were restricted to the Llano de Paciencia. During this period of aridity the groundwater silcrete formed creating a resistant layer that was preserved across the region.

During deposition of the Upper Vilama Gravels the eastern part of the Cordillera de la Sal started to uplift rapidly along the Cordillera de la Sal Frontal Thrust. Uplift resulted in back-tilting of the region between the North Dome and Valle de la Luna towards the northwest (Fig. 14 I). The Vilama sediments within the eastern region of the Cordillera de la Sal were then subject to erosion and transported to the northwest into the Llano de Paciencia infilling the topography created by faults to form the present day fluvial network within the earliest Pleistocene (Fig. 4).

\section{Discussion}

The Vilama Formation was deposited from the Late Miocene to earliest Pleistocene and consists of six distinct facies associations: volcaniclastic, meandering fluvial, distal alluvial fan, distal alluvial-mudflat-lacustrine, distal alluvial-lacustrine and palustrine carbonate. Post-sedimentary diagenesis formed a distinct groundwater silcrete across the region. The type and regional distribution of the facies associations is controlled by a combination of climate and halokinesis related to compressional tectonics (Fig. 15).

\subsection{Regional vs. Local Climate Signature}

Within northern Chile numerous studies have looked at changes in climate. In particular, studies have focused on when the region became hyperarid (e.g. Jordan et al. 2014). The timing of this shift in climate is important, as it has been linked with numerous causes; the timing of uplift of the Andes creating a rainshadow effect (e.g. 
Alpers and Brimhall, 1988), global shifts in the climate (Evenstar et al. 2009), a combination of ocean circulation patterns (Hartley, 2003; Hartley et al. 2005; Sáez et al. 2012; Jordan et al. 2014), global atmospheric circulation patterns (Hartley et al. 2005) and continentality (Hartley et al. 2005). Currently the age for this switch to hyperaridity ranges from the Triassic (Clark et al. 2006) to the late Pliocene (Hartley and Chong, 2002; Hartley, 2003) and Pleistocene (Jordan et al. 2014). Even within the Quaternary, brief phases of less arid conditions are recorded (Quade et al. 2008; Rech et al. 2006; Gayo et al. 2012, Jordan et al. 2014) in the Central Atacama.

A major factor in constraining when the region became hyperarid is distinguishing local climate effects from regional events but this can be difficult. Within the Salar de Atacama and Calama basin, lake levels can largely be controlled by groundwater discharge from aquifers supplied from elevations in the higher Western Cordillera rather than through direct precipitation within the Atacama Desert. So, while lake levels within these regions may be high they may not link directly to an increase in precipitation within the Atacama Desert. However, by comparing the Vilama Formation with similar age sediments from northern Chile and southern Peru, a regional climate control can be distinguished from more local effects in the Salar de Atacama.

During the Mid-Miocene to Late Miocene ( $17 \mathrm{Ma}-9.5 \mathrm{Ma}$ ) a shift in the climate to more hyperarid conditions led to a hiatus of $\sim 8 \mathrm{Myr}$ in sedimentation within the Cordillera de la Sal between deposition of the Paciencia Group and the Vilama Formation (Fig. 15). This can be correlated locally with a hiatus in sedimentation between the Jalquinche and Opache Formations and the Lasana and Chiquinaputo Formations in the Calama Basin (May et al. 1999) and paleosol formation along the south east of the Calama Basin (Rech et al. 2006). More regionally, a decrease in sedimentation and formation of paleosurfaces is recognized throughout southern Peru (Pampa Sitana Planation Surface (Quang et al. 2005)) into northernmost Chile (Quebrada Camina and Quebrada Suca (Pinto et al. 2004), the Pica region (Victor et al. 2004), Quebrada Aroma (Farías et al. 2005), southern Pampa del Tamarugal (Jordan et al. 2014) and into Central northern Chile (the Atacama gravels 
(Nishizummi et al. 2005)). Throughout northern Chile and southern Peru this time also represents a decrease in supergene enrichment of copper porphyry deposits (Alpers and Brimhall, 1988, Hartley and Rice, 2005). All of these have been interpreted as due to an increase in aridity in the Mid-Miocene (Alpers and Brimhall, 1988, Hartley and Rice, 2005; Nishizummi et al. 2005) due to either uplift of the Andes or related to the Mid-Miocene Climatic Optimum (Evenstar et al. 2009).

From $\sim 9$ Ma onwards, within the Cordillera de la Sal region, an increase in humidity increased sediment input into the region depositing the Lower Vilama Gravel sequence (Fig. 15). This corresponds to an increase in sedimentation recorded with alluvial and lake deposits within the Calama Basin (Chiquinoputo Fm)(May et al. 1999) and the Quillagua-Llamara Basin (Hilaricos Fm) (Sáez et al. 2012). Within the Precordilleran Basins, sedimentation increased in a number of basins (Lauca, Caragua and Pampa Caya areas) indicating precipitation within the Precordillera at this time with sediment shedding westward into the basins (Hartley and Evenstar, 2010).

From $~ 8.5 \mathrm{Ma}$ to $6 \mathrm{Ma}$ there is a decrease in sedimentation within the Cordillera de la Sal. This correlates with an increase in aridity also recognised within the Calama Basin, Quillagua-Llamara Basin and the Lauca Basin within northernmost Chile (Hartley and Evenstar, 2010, Sáez et al. 2012).

From $6 \mathrm{Ma}$ to $2 \mathrm{Ma}$ lake conditions prevailed across the Cordillera de la Sal with deposition of the Vilama Carbonate and Vilama Minibasin Mudstones in the Cordillera de la Sal up to $3.5 \mathrm{Ma}$ (Fig. 15). After this time, a decrease in water depth and/or salt movement led to widespread deposition of the Vilama Redbeds across the entire Cordillera de la Sal region. These wetter conditions prevailed until at least $2.0 \pm 0.9 \mathrm{Ma}$ (Naranjo et al. 1994). This period correlates with increasing sedimentation within the Calama Basin (Opache Fm and later parts of the Chiquinoputo Fm) and Quillagua-Llamara Basin (Quillagua Fm) and alluvial fan formation within the southern Pampa del Tamarugal (Jordan et al. 2014).

This article is protected by copyright. All rights reserved. 
Within the Calama Basin and Quillagua-Llamara Basin large-scale sedimentation ceased at $\sim 3 \mathrm{Ma}$. This has been interpreted to be due to the climate reverting to present day hyperarid conditions (May et al. 1999; Hartley and Chong, 2002). However the sharp difference in sedimentary style between the Calama Basin and Salar de Atacama Basin, which are geographically close ( $25 \mathrm{~km})$, suggests that a more local effect is likely. Within the Salar de Atacama Basin the drainage is endorheic so is unaffected by changes in sea level. The Calama and QuillaguaLlamara Basins,, however, are linked to the Pacific Ocean by the Rio Loa. At 3 Ma the Rio Loa is believed to have incised through the Coastal Cordillera to the Pacific Ocean creating exorheic drainage conditions (May et al. 1999; Rech et al. 2010). The drop in base level could explain the decrease in sedimentation within the Calama and Quillagua-Llamara Basin (May et al. 1999) while maintaining lake conditions within the Salar de Atacama Basin. The switch in sedimentation rate in the Calama Basin, could therefore be a reflection of drainage capture rather than climate change.

Within the Cordillera de la Sal, humid conditions prevailed up till the earliest Pleistocene ( $2 \mathrm{Ma}-1 \mathrm{Ma}$ ) when a switch from lake conditions to the Upper Vilama Gravels records a change to hyperarid conditions (Fig. 15). This switch from high lake levels to hyperarid conditions is much later than previous literature has suggested for this region (Hartley and Chong, 2002, Hartley, 2003). However these data correlate with the relict landscapes dated in this region using cosmogenic isotope exposure ages (Plaszek et al. 2010) and alluvial fan surfaces within the southern Pampa del Tamarugal (Jordan et al. 2014).

After this period, a number of short-lived humid events have been recorded in the late Pleistocene and Holocene. In particular, this is illustrated by high lake levels within the Altiplano and Chilean highland (Grosjean et al. 2001, Placzek et al. 2009), biotaxa and archaeology within the Pampa del Tamarugal (Gayo et al. 2012), and evaporites within the Quillagua-Llamara Basins and paleowetlands (Bobst et al. 2001, Quade et al. 2008). Within the Salar de Atacama, paleowetlands are recorded at a number of intervals within the Late Pliestocene and Holocene, with a

This article is protected by copyright. All rights reserved. 
continental lake from 26.7 to 16.5 ka within the central part of the Salar (Bobst et al. 2001, Quade et al. 2008). However the Vilama Formation records the last large lake present within the Salar de Atacama Basin.

The primary control on changes in sedimentation within the Cordillera de la Sal is climatic, however the regional extent of this climatic signature is debatable. During the Mid-Miocene changes in climate are recorded in facies changes, occurrence of hiatuses, paleosol types, paleosurface formation, timing of supergene enrichment and cosmogenic exposure ages throughout northern Chile and southern Peru. The wide range of areas affected by this change suggests that it was related to a large scale regional control possibly due to either the uplift of the Andes creating a rainshadow at this time or due to the global Mid-Miocene Climatic Optimum (Evenstar et al. 2009).

Later events from 9 Ma to $6 \mathrm{Ma}$ are much more local only affecting the PreAndean basins. Climate events in this region from 7 Ma to 5.5 Ma have previously been related to changes in the Humboldt current which in turn can be related to glaciation in the Antarctic ice sheets and ocean thermocline shallowing (Sáez et al. 2012). However the local nature of these events could be correlated to increases in precipitation within the Western Cordillera rather than direct precipitation within the Atacama Desert. These in turn are likely to be related to precipitation spilling over the Andes from the east due to shifts in the Bolivian high, an upper level tropospheric anticyclone positioned over the Altiplano which can vary due to variations in Amazonian rainfall (Lenters and Cook, 1997). Alternatively increases in winter precipitation could be due to northward displacements of the cold air masses from the Pacific causing precipitation in the southern Atacama Desert $\left(23^{\circ} \mathrm{S}\right.$ and $\left.25^{\circ} \mathrm{S}\right)$ and along the western margin of the Andes (Vuille and Ammann, 1997).

Events after $6 \mathrm{Ma}$ are restricted to the Central Atacama basins of the Calama Basin, Salar de Atacama Basin, southern Pampa del Tamarugal and Quillagua-Llamara Basins suggesting a climatic event local to the Central Atacama region. As discussed above this could be caused by northward displacements of the cold air masses from the Pacific, which could be restricted to only affecting this region (Vuille and 
Ammann, 1997). Alternatively climate fluctuations from $5 \mathrm{Ma}$ onwards within the southern Pampa del Tamarugal have been closely linked with variations within sea surface temperature (Jordan et al. 2014) and could correlate through to the Salar de Atacama.

\subsection{Tectonic controls}

The cause of salt movement within the Cordillera de la Sal is still debated. Initial studies suggested that salt movement was the result of an emergent thrust front migrating from the Cordillera de Domeyko into the Cordillera de la Sal in the mid Miocene (Jolley et al. 1990, Muñoz et al. 2000, Ruetter et el. 2006) (Fig. 3a). However, later seismic studies proposed that the Cordillera de la Sal was generated by gravity upwelling of salt generated by reverse thrusting on the Tulor fault to the east of the Cordillera de la Sal through the Mid Miocene to Pliocene (Panamount et al. 2004 and Jordan et al. 2007) (Fig. 3b). The salt withdrawal from surrounding areas created steep reverse faults on either side of the Cordillera.

Structural analysis of the region together with the distribution of the Vilama Formation shows this area to have been an area of active thrusting since the MidMiocene. All faults within the area are thrust faults, consistent with the idea that the Cordillera de la Sal forms part of a thrust front margin that originates within the Cordillera de Domeyko supporting either thin-skinned thrusting within the Cordillera de la Sal (Jolley et al. 1990, Muñoz et al. 2000, Ruetter et el. 2006) or thick-skinned thrusting (Muñoz et al. 2002).

Salt movement is seen to initiate within the western region of the Cordillera de la Sal by the Mid-Miocene forming a wide ( $\sim 4 \mathrm{~km})$ salt wall (Fig. 15). Salt movement does not initiate on the eastern edge of the Cordillera de la Sal until $5.5 \mathrm{Ma}$ - 3.5 Ma where smaller salt pod (minibasin) structures $(<1 \mathrm{~km})$ are created (Fig. 15). During the Mid-Miocene the western salt wall was breached and the Central Dome started to subside creating an area of active sediment accumulation. Salt movement was only initiated again within the Pleistocene when the eastern edge of the Cordillera de la Sal uplifted, folding the Vilama 
Formation (Fig. 14 I) and tilting the entire Cordillera westwards so it drained back into the Llano de Paciencia.

The salt morphology and rates of salt movement have a significant control on the distribution of the sediments within the Vilama Formation. The initial salt morphology created by uplift of the Cordillera de la Sal in the late Miocene created a barrier to eastward dispersal of sediment from the Cordillera de Domeyko. This allowed relatively coarse-grained sediments, originating from the Cordillera de Domeyko, to accumulate proximal to the western edge of the salt wall. However the eastern edge would have been cut off from its sediment supply limiting sedimentation to finer grained sediments. Likewise the rapid uplift of the eastern salt wall in the Early Pliocene creating the minibasins would have isolated the basins they created restricting sediment input into the minibasins. This factor combined with a more humid climate resulted in deposition of fine grained lacustrine sediments in the minibasins and along the eastern margin of the Cordillera de la Sal. In similar paleogeographic settings from the salt related minibasins of the Saigak oil field, Kazakhstan, coarse grained sediments are restricted to fluvial pathways, while isolated basins are infilled with lacustrine sediments (Barde et al. 2002).

During the Late Pliocene the Central Dome collapsed between the northern and southern dome, again altering the salt dome morphology (Fig 15). This created a pathway for sediment transport across the Llano de Paciencia which allowed coarse-grained sediments to accumulate close to the Northern and Southern salt domes and over the smaller salt domes created along the eastern edge of the Cordillera de la Sal. However this could only occur where sediment supply outpaced salt related uplift. In the Late Pleistocene the rapid uplift along the Cordillera de la Sal Primary Frontal Thrust on the eastern edge of the Cordillera outpaced sedimentation closing the previous fluvial pathway and again limiting sedimentation to within the Llano de Paciencia (Fig. 15).

An important factor in controlling both sediment distribution and preservation is accommodation generation. Within the Llano de Paciencia the underlying Paciencia Group demonstrates salt evacuation into the Cordillera de la Sal. This

This article is protected by copyright. All rights reserved. 
increased the accommodation space within the basin allowing greater accumulation and preservation of sediments within this region. The salt dissolution feature, the Central Dome, between the north and south dome again provided an area of increased accommodation allowing the accumulation of thick volumes of the distal alluvial-mudflat-lacustrine facies here. Sediments are more readily preserved within the salt dissolution feature, as later salt movement does not lead to their subsequent erosion.

\section{Conclusion}

The Vilama Formation in northern Chile records alluvial fan-fluvial-lacustrine interactions with climate and salt diapirism since the Miocene (Fig 15). The Cordillera de la Sal is shown to be part of a thrust front margin that most likely originates within the Cordillera de Domeyko in the Mid-Miocene. Since that time, facies distribution proximal to the salt diapirs was controlled by a combination of regional and local climate fluctuations and halokinesis.

Previous research throughout northern Chile and southern Peru has led to a range of proposed different ages for the switch to hyperaridity. By comparing the Vilama Formation with similar age strata throughout northern Chile and southern Peru, we have shown that climate change within the region appears to be largely diachronous with the last regional event in the Mid-Miocene. Since that time, periodic humid events have occurred but have been restricted to either Precordilleran basins or the Central Atacama. Within the Central Atacama the final switch to present day hyperarid conditions did not occur until the late Pliocene- earliest Pleistocene, much later than previously estimated from the neighbouring Calama Basin and supporting recent work by Jordan et al. (2014) within the southern Pampa del Tamarugal.

The salt movement of the Cordillera de la Sal controls both the distribution and facies type of the Vilama Formation. Facies type is controlled by salt morphology by either trapping coarser sediments from the source area by rapidly uplifting salt bodies basinward or by limiting sediments to finer grained facies by isolating basins within uplifted salt bodies in the hinterland. Accommodation created by

This article is protected by copyright. All rights reserved. 
subsidence related to withdrawing salt bodies also plays a role in deposition and preservation of sediments.

The structure within the Cordillera de la Sal is controlled by diapiric salt related uplift associated with thrust faults across the region. The region has been an area of compressional deformation since the Oligocene. Most likely compression originated as part of a thrust front margin from the Cordillera de Domeyko, supporting either thin-skinned thrusting within the Cordillera de la Sal (Jolley et al. 1990, Muñoz et al. 2000, Ruetter et el. 2006) or thick-skinned thrusting (Muñoz et al. 2002). The resulting stratigraphy is shown to be a complex interplay between compressional tectonics, halokinesis and both local and regional climate change.

\section{Acknowledgements.}

This material is based upon work supported by ConocoPhilips, BG Group, and ENI. BHP Billiton are acknowledged for their support in the final stages of analysis and preparation of this manuscript. This manuscript benefitted greatly from reviews by Alberto Sáez and Teresa Jordan. We are grateful to Rhiannon Chaloner for help with fieldwork.

\section{References.}

Alpers, C.N., Brimhall, G.H., 1988. Middle Miocene Climatic-Change in the Atacama Desert, Northern Chile - Evidence from Supergene Mineralization at La-Escondida. Geological Society of America Bulletin 100, 1640-1656.

Arriagada, C., Cobbold, P., Mpodozis, C., Roperch, P., 2002. Cretaceous to Paleogene compressional tectonics during the deposition of the Purilactis Group, Salar de Atacama, Proceeds V IRD-ISAG, Toulouse, pp. 41 - 44.

This article is protected by copyright. All rights reserved. 
Barde, J.-P., Chamberlain, P., Galavazi, M., Harwijanto, J., Marsky, J., Gralla, P., van den Belt, F., 2002. Sedimentation during halokinesis: Permo-Triassic reservoirs of the Saigak Field, Precaspian Basin, Kazakhstan. Petroleum Geoscience 8, 177 - 187.

Blanco, N., Mpodozis, C., Gardeweg, M., Jordan, T., 2000. Sedimentación del Mioceno Superior-Plioceno en la cuenca del Salar de Atacama. Estratigrafia de la Formación Vilama, II Region de Antofagasta, Proc. IX Congreso Geologico Chileno Puerto Varas, Chile, pp. 446-450.

Bobst, A.L., Lowenstein, T.K., Jordan, T.E., Godfrey, L.V., Ku, T.-L. \& Luo, S., 2001. A 106 Ka Paleoclimate Record from Drill Core of the Salar De Atacama, Northern Chile. Palaeogeography, Palaeoclimatology, Palaeoecology, 173, 21-42.

Clarke, J.D.A., 2006. Antiquity of aridity in the Chilean Atacama Desert. Geomorphology 73, 101-114.

Dingman 1965, Quadrangulo San Pedro de Atacama, Carta no. 14, Carta Geologica de Chile: Santiago, Chile, Instituto de Investigaciones Geoligcas, 29

Dunai, T.J., Lopez, G.A.G. \& Juez-Larre, J., 2005. Oligocene-Miocene Age of Aridity in the Atacama Desert Revealed by Exposure Dating of Erosion-Sensitive Landforms. Geology, 33, 321-324.

Evenstar, L.A., Hartley, A.J., Stuart, F.M., Mather, A.E., Rice, C.M., Chong, G., 2009. Multiphase development of the Atacama Planation Surface recorded by cosmogenic He-3 exposure ages: Implications for uplift and Cenozoic climate change in western South America. Geology 37, 658-658.

Farías, M., Charrier, R., Comte, D., Martinod, J., Hérail, G., 2005. Late Cenozoic deformation and uplift of the western flank of the Altiplano: Evidence from the depositional, tectonic, and geomorphologic evolution and shallow seismic activity (northern Chile at $19^{\circ} 30^{\prime}$ S). Tectonics 24, TC4001.

This article is protected by copyright. All rights reserved. 
Flint, S., 1985. Alluvial fan and playa sedimentation in an Andean arid closed basin: The Paciencia Group, Antofagasta Province, Chile. Journal of the Geological Society $142,533-546$.

Flint, S., Turner, P., Hartley, A., Jolley, E., 1991. From Foreland Rift to Fore-Arc Basin - Tectonothermal Controls on Subsidence and Stratigraphic Development in the Mesozoic-Recent Salar-De-Atacama Basin, Chilean Andes. AAPG Bulletin-American Association of Petroleum Geologists 75, 575-575.

Flint, S., Turner, P., Jolley, E.J., Hartley, A.J., 1993. Extensional Tectonics in Convergent Margin Basins - an Example from the Salar-De-Atacama, Chilean Andes. Geological Society of America Bulletin 105, 603-617.

Gayo, E.M., Latorre, C., Santoro, C.M., Maldonado, A.., De Pol-Holz, R 2012. Hydroclimate variability in the low-elevation Atacama Desert over the last $2500 \mathrm{yr}$, Climate of the Past 8, 287-306.

Gardeweg, M., and Ramírez, C.F., 1987. La Pacana caldera and the Atana Ignimbrite - a major ash-flow and resurgent caldera complex in the Andes of northern Chile. Bulletin of Volcanology, 49, 547-566.

Grosjean, M., van Leeuwen, J., van der Knapp, W., Geyh, M., Ammann, B., Tanner, W., Messerli, B., Núñez, L., Valero-Carcés, B., Veit, H., 2001. A 22,000 ${ }^{14}$ C year BP sediment and pollen record of climate change from Laguna Miscanti $\left(23^{\circ} \mathrm{S}\right)$, northern Chile. Global and Planetary Change. 28, 35-51.

Hartley, A.J., 2003. Andean uplift and climate change. Journal of the Geological Society $160,7-10$.

Hartley A. J., and Chong G., 2002. Late Pliocene age for the Atacama Desert: Implications for the desertification of western South America. Geology 3, 43 - 46. 
Hartley, A.J., Chong, G., Houston, J., Mather, A.E., 2005. 150 million years of climatic stability: evidence from the Atacama Desert, northern Chile. Journal of the Geological Society 162, 421-424.

Hartley, A.J., Evenstar, L., 2010. Cenozoic stratigraphic development in the north Chilean forearc: Implications for basin development and uplift history of the Central Andean margin. Tectonophysics 495, 67-77.

Hartley, A.J., Flint, S., Turner, P., Jolley, E.J., 1992. Tectonic Controls on the Development of a Semiarid, Alluvial Basin as Reflected in the Stratigraphy of the Purilactis Group (Upper Cretaceous-Eocene), Northern Chile. Journal of South American Earth Sciences 5, 275-296.

Hartley, A.J., Rice, C.M., 2005. Controls on supergene enrichment of porphyry copper deposits in the Central Andes: A review and discussion. Mineralium Deposita $40,515-525$.

Hollingworth, S.E., Rutland, R.W.R., 1968. Studies of Andean uplift part I-postcretaceous evolution of the San Bartolo Area, North Chile. Geological Journal 6, 4962.

Jolley, E.J., Turner, P., Williams, G.D., Hartley, A.J., Flint, S., 1990. Sedimentological Response of an Alluvial System to Neogene Thrust Tectonics, Atacama Desert, Northern Chile. Journal of the Geological Society 147, 769-784.

Jordan, T.E., Kirk-Lawlor, N.E., Blanco P., N., Rech, J.A. \& Cosentino, N.J., 2014. Landscape Modification in Response to Repeated Onset of Hyperarid Paleoclimate States since $14 \mathrm{Ma}$, Atacama Desert, Chile. Geological Society of America Bulletin. B30978.1

This article is protected by copyright. All rights reserved. 
Jordan, T.E., Mpodozis, C., Munoz, N., Blanco, N., Pananont, P., Gardeweg, M., 2007. Cenozoic subsurface stratigraphy and structure of the Salar de Atacama Basin, northern Chile. Journal of South American Earth Sciences 23, 122-146.

Kape, S.J., 1996. Basin analysis of the Oligo-Miocene Salar de Atacama basin, northern Chile. University of Birmingham, p. 256.

Lenters, J.D. \& Cook, K.H. 1997. On the Origin of the Bolivian High and Related Circulation Features of the South American Climate. Journal of the Atmospheric Sciences, 54, 656-678.

Macellari, C.E., Su, M., Townsend, F., 1991. Structure and seismic stratigraphy of the Atacama Basin, Northern Chile, Proc. VI Congr. Geol. Chileno, pp. 133 - 137.

Marinovic, N., Lahsen, A., 1984. Carta Geologica de Chile 1:250,000 Hoja Calama, Servicio Nacional de Geologia y Mineria. , pp. 1 - 150.

May, G., Hartley, A.J., Stuart, F.M., Chong, G., 1999. Tectonic signatures in arid continental basins: an example from the Upper Miocene-Pleistocene, Calama Basin, Andean forearc, northern Chile. Palaeogeography Palaeoclimatology Palaeoecology $151,55-77$.

Mortimer, C., Saric, N., 1975. Cenozoic Studies in Northernmost Chile. Geologische Rundschau, 64, 395-420.

Mpodozis, C., Arriagada, C., Basso, M., Roperch, P., Cobbold, P., Reich, M., 2005. Late Mesozoic to Paleogene stratigraphy of the Salar de Atacama Basin, Antofagasta, Northern Chile: Implications for the tectonic evolution of the Central Andes. Tectonophysics 399, 125-154.

This article is protected by copyright. All rights reserved. 
Munoz, J., Charrier, R., Reutter, K.J., 1997. Evolución de la Cuenca del Salar de Atacama: Inversión tectónica y relleno de una cuenca de antepaís de retroarco. Proc. VIII Congr. Geol. Chileno, pp. 5 - 199.

Munoz, N., Charrier, R., Jordan, T., 2002. Interactions between basement and cover during the evolution of the Salar de Atacama Basin, northern Chile. Revista Geologica De Chile 29, 55-80.

Muñoz, N., Charrier, R., Radic, J.P., 2000. Formación de la Cordillera de la Sal por propagación de fallas y plegamiento por despegue, II Región, Chile, IX Congreso Geológico Chileno, pp. 604 - 608.

Naranjo, J.A., Ramirez, C.F., Paskoff, R., 1994. Morphostratigraphic Evolution of the Northwestern Margin of the Salar-De-Atacama Basin (23-Degrees-S-68-Degrees-W). Revista Geologica De Chile 21, 91-103.

Naranjo, J.A., Ramirez, C.F., Paskoff, R., 1994. Morphostratigraphic Evolution of the Northwestern Margin of the Salar-De-Atacama Basin (23-Degrees-S-68-Degrees-W). Revista Geologica De Chile 21, 91-103.

Nishiizumi, K., Caffee, M.W., Finkel, R.C., Brimhall, G., Mote, T., 2005. Remnants of a fossil alluvial fan landscape of Miocene age in the Atacama Desert of northern Chile using cosmogenic nuclide exposure age dating. Earth and Planetary Science Letters 237, 499-507.

Pananont, P., Mpodozis, C., Blanco, N., Jordan, T.E., Brown, L.D., 2004. Cenozoic evolution of the northwestern Salar de Atacama Basin, northern Chile. Tectonics 23, TC6007.

Pinto, L., Hérail, G., Charrier, R., 2004. Syntectonic sedimentation associated with Neogene structures in the Precordillera of Moquella Zone, Tarapacá (19¹5'S, northern Chile). Revista Geologica De Chile 31, 19-44. 
Placzek, C.J., Matmon, A., Granger, D.E., Quade, J., Niedermann, S., 2010. Evidence for active landscape evolution in the hyperarid Atacama from multiple terrestrial cosmogenic nuclides. Earth and Planetary Science Letters 295, 12-20.

Placzek, C., Quade, J., Betancourt, J.L., Patchett, P.J., Rech, J.A., Latorre, C.,

Matmon, A., Holmgren, C., English, N.B., 2009. Climate in the dry central Andes over geologic, millennial, and interannual timescales. Annals of the Missouri Botanical Garden 96, 386- 397

Quade, J., Rech, J.A., Betancourt, J.L., Latorre, C., Quade, B., Rylander, K.A., Fisher, T., 2008. Paleowetlands and regional climate change in the central Atacama Desert, northern Chile. Quaternary Research 69, 343-360.

Quang, C.X., Clark, A.H., Lee, J.K.W., Hawkes, N., 2005. Response of supergene processes to episodic Cenozoic uplift, pedimeńt erosion, and ignimbrite eruption in the Porphyry Copper Province of southern Perú. Economic Geology 100, 87-114.

Ramírez, C.F., 1979. Geología del Cuadrángulo Río Grande y sector nororiental del Cuadrángulo Barros Arana, Provincia El Loa, II región, Departamento de Geología Universidad de Chile, Santiago, p. 139.

Rech, J.A., Currie, B.S., Michalski, G., Cowan, A.M., 2006. Neogene climate change and uplift in the Atacama Desert, Chile. Geology 34, 761-764.

Rech, J.A., Currie, B.S., Shullenberger, E.D., Dunagan, S.P., Jordan, T.E., Blanco, N., Tomlinson, A.J., Rowe, H.D., Houston, J., 2010. Evidence for the development of the Andean rain shadow from a Neogene isotopic record in the Atacama Desert, Chile. Earth and Planetary Science Letters 292, 371-382.

Ruetter, K.-J., Charrier, R., Götze, H.-J., Schurr, B., Wigger, P., Scheuber, E., Giese, P., Reuther, C.-D., Schmidt, S., Rietbrock, A., Chong, G., Belmonte-Pool, A., 2006. The Salar de Atacama Basin: a Subsiding Block within the Western Edge of the 
Altiplano-Puna Plateau, in: Oncken, O., Chong, G., Franz, G., Giese, P., Götze, H.-J., Ramos, V.A., Strecker, M.R., Wigger, P. (Eds.), The Andes.

Sáez, A., Cabrera, L., Garcés, M., Bogaard, P., Jensen, A., Gimeno, D., 2012. The stratigraphic record of changing hyperaridity in the Atacama desert over the last 10 Ma. Earth and Planetary Science Letters 355, 32-38.

Sáez, A., Cabrera, L., Jensen, A., Chong, G., 1999. Late Neogene lacustrine record and palaeogeography in the Quillagua-Llamara basin, Central Andean fore-arc (northern Chile). Palaeogeography Palaeoclimatology Palaeoecology 151, 5-37.

Salisbury, M.J., Jicha, B.R., De Silva, S.L., Singer, B.S., Jiménez, N.C. \& Ort, M.H., 2010. 40Ar/39Ar Chronostratigraphy of Altiplano-Puna Volcanic Complex Ignimbrites Reveals the Development of a Major Magmatic Province. Geological Society of America Bulletin B30280.1

Schurr, B., Rietbrock, A., 2004. Deep seismic structure of the Atacama basin, northern Chile. Geophysical Research Letters 31, L12601.

Sillitoe, R. H., Mortimer, G, Clark, A. H., 1968. A chronology of landform evolution and supergene mineral alteration, southern Atacama Desert, Chile. Institution of Mining and Metallurgy, Transactions, Section B: Applied Earth Sciences. 77, B166BI69.

Silva, D., 1989. Geochronology and stratigraphy of the ignimbrites from the $21^{\circ} 30^{\prime} \mathrm{S}$ to $23^{\circ} 30^{\prime} \mathrm{S}$ portion of the Central Andes of northern Chile. Journal Volcanology and Geothermal Research 37, 93 - 131.

Thiry, M., Milnes, A.R., Rayot, V., Simon-Coincon, R., 2006. Interpretation of palaeoweathering features and successive silicifications in the Tertiary regolith of inland Australia. Journal of the Geological Society 163, 723-736.

This article is protected by copyright. All rights reserved. 
Tucker, M., 2011. Sedimentary Rocks in the Field: A Practical Guide (Geological Field Guide).

Victor, P., Oncken, O., Glodny, J., 2004. Uplift of the western Altiplano plateau:

Evidence from the Precordillera between $20^{\circ}$ and $21^{\circ} \mathrm{S}$ (northern Chile). Tectonics 23, TC4004.

Vuille, M., Ammann, C., 1997. Regional snowfall patterns in the high, arid Andes. Climatic Change 36, 413-423.

Wilkes, E., Görler, K., 1994. Sedimentary and Structural Evolution of the Salar de Atacama, Northern Chile, in: Wigger, P., Reutter, K.J. (Eds.), Tectonics of the Southern Central Andes, pp. 171-188.

\section{Figures}

Figure 1; A) DEM of Northern Chile and Southern Peru. The study region is shown within the black box and more closely in B. B shows a satellite image from Google Earth of the Salar de Atacama. B also shows the location of cross section (line A-B) shown in Figure 3. Black box C shows the location of Figure 4.

Figure 2; Stratigraphic column of the Salar de Atacama Basin. VC-Vilama Carbonates, VMM-Vilama Minibasin Mudstones, Hollingworth G - Hollingworth gravels. Stars represent volcanic age constraints on the Vilama Formation; a) $2.0 \pm$ $0.9 \mathrm{Ma}$ (Naranjo et al. 1984) b) $3.7 \pm 1.0 \mathrm{Ma}$ (Blanco et al. 2000) c) $5.82 \pm 0.08 \mathrm{Ma}$ (Salisbury et al. 2010) d) $8.33 \pm 0.06 \mathrm{Ma}$ (Salisbury et al. 2010) e) $9.40 \pm 0.03 \mathrm{Ma}$ (Salisbury et al. 2010) and f) $17 \pm 2$ Ma (Ramírez et al. 1979).

Figure 3; Two different interpretations of the structural cross sections across the Cordillera Domeyko, Cordillera de la Sal and into the Salar de Atacama. Location of cross section shown in figure 1. A is based on data from Jolley et al. 1990. B is based 
on data from Panamount et al. 2004.Figure 4; Map of the study area showing location of cross sections, sedimentary logs and the present day geomorphology. Sedimentary logs (1-9) are shown as L1-9 and cross sections (S-T, V-W and Y-Z) are shown in Figure 12.

Figure 4; Map of the study area showing location of cross sections, sedimentary logs and the present day geomorphology. Sedimentary logs (1-9) are shown as L1-9 and cross sections (S-T, V-W and $Y-Z)$ are shown in Figure 12.

Table 1; Facies description and interpretation

Table 2; Facies associations and interpretations

Figure 5; Key for figures 6, 7 and 8.

Figure 6; A. Sedimentary log of part of the meandering fluvial facies showing interbedded channel conglomerates, sheet sandstones and siltstones from log 1 (Fig. 4). Paleocurrents directions are measured from imbricated clasts. B. Photograph of the downlapping lateral accretion surfaces in fluvial facies.

Figure 7; Sedimentary log of part of the distal alluvial-lacustrine diatomite facies association from log 2(left) and log 3 (right).

Figure 8; Log of the palucustrine carbonate from Log 1.

Figure 9; Palustrine carbonate A) travertine beds, B) stromatolite beds (S) with overlying peloidal grainstones (G); C) Thin-section detail (PPL) of stromatolite layer (S) with overlying fine peloidal grainstone (G) which displays vuggy porosity (V); D) Thin-section detail (PPL) of peloidal (P) - bioclastic grainstone with ostracods (arrowed).

Figure 10; Regional distribution of the Vilama Formation across the Cordillera de la Sal.

This article is protected by copyright. All rights reserved. 
Figure 11; Chronostratigraphic correlation of the Mid Miocene to Recent basin-fill of the Cordillera de la Sal region. Key for lithotypes in Figure 10. LVG- Upper Vilama Gravels, VC-Vilama Carbonates, VMM-Vilama Minibasin Mudstones, VR-Vilama Redbeds and UVG- Upper Vilama Gravels.

Figure 12; Three cross sections across the Cordillera de la Sal. Exact locations shown in Figure 4. EFT- Eastern Frontal Thrust, VDM - Valle de la Muerte Thrust Fault, PFTPrimary Frontal Thrust Fault, MB1- Minibasin 1, MD2- Minibasin 2.

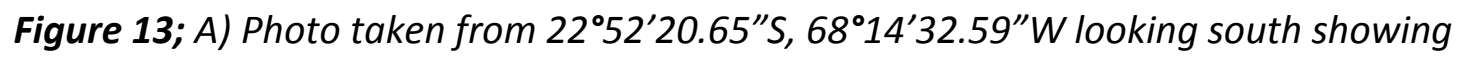
thrust faults cutting through the Paciencia group and fault tip folding in the groundwater silcreted Upper Vilama Gravels. B) Photo taken from $22^{\circ} 54^{\prime} 46.70^{\prime \prime}$, $68^{\circ} 13^{\prime} 32.67^{\prime \prime}$ W looking south west. Photo of distal alluvial-lacustrine diatomite facies in eastern part of minibasin 2. Facies shows thinning to the left of the photo formed in response of salt tectonics from Early to Mid Pliocene responsible for formation of the minibasins and later deformation and folding by the Primary Frontal Thrust Front to the east of the area during the early Pleistocene.

Figure 14; Evolution of the Cordillera de la Sal since the Mid-Miocene.

Figure 15; Figure showing summary of lithologies, climate and tectonics movement since the Early-Miocene within the Northern Part of the Cordillera de la Sal. LVGUpper Vilama Gravels, VC- Vilama Carbonates, VMM- Vilama Minibasin Mudstones, VR-Vilama Redbeds and UVG- Upper Vilama Gravels.

This article is protected by copyright. All rights reserved. 


\begin{tabular}{|c|c|c|c|c|}
\hline $\begin{array}{l}\text { Facies } \\
\text { ensecienton }\end{array}$ & Facher & Utroderg and aed haver & 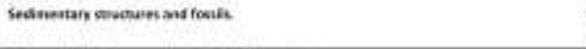 & ineverecatiase \\
\hline $\begin{array}{l}\text { Vukarikartic } \\
\text { depribs. }\end{array}$ & vi & 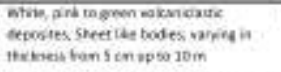 & 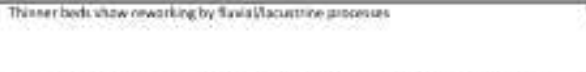 & 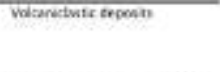 \\
\hline \multirow[t]{2}{*}{ Fusual } & 므 & 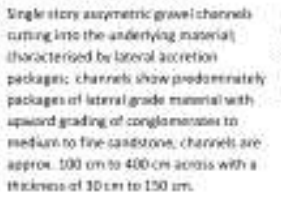 & 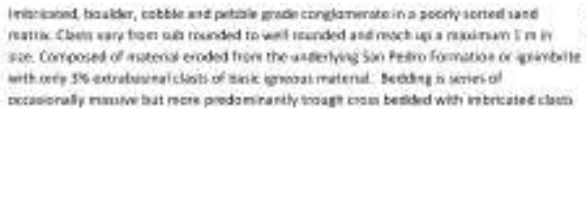 & 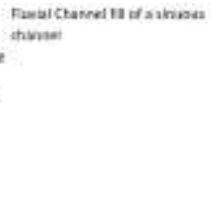 \\
\hline & it & 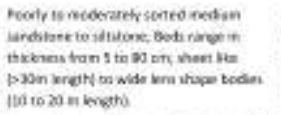 & 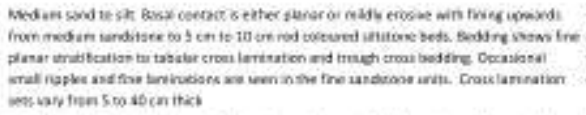 & 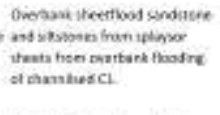 \\
\hline Alowed kan & D & 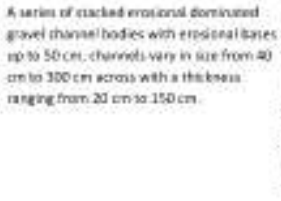 & 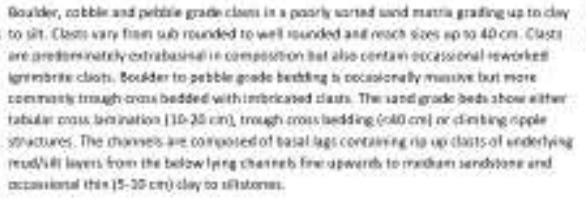 & 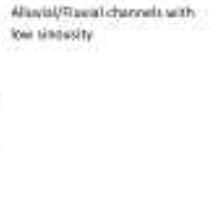 \\
\hline \multirow[t]{5}{*}{ 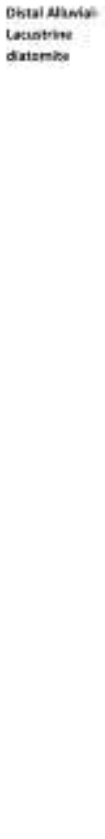 } & 52 & 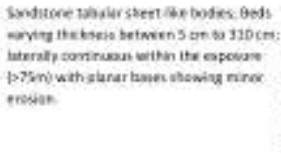 & 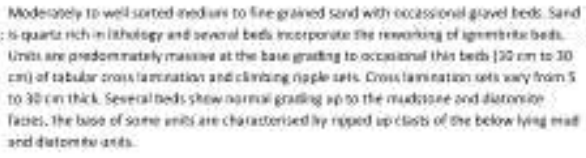 & 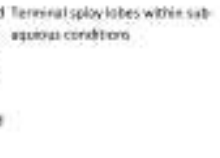 \\
\hline & Mn & 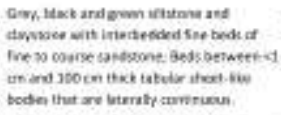 & 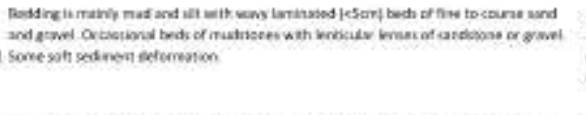 & 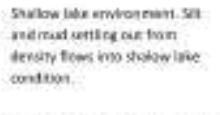 \\
\hline & we & 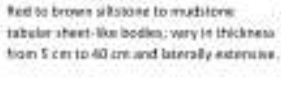 & 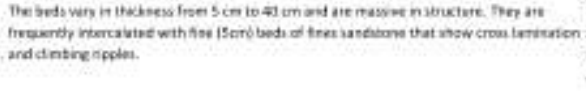 & 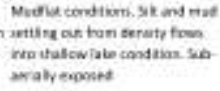 \\
\hline & 0 & 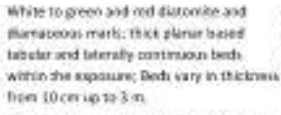 & 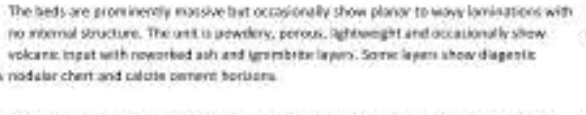 & 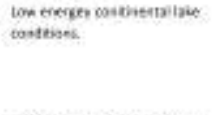 \\
\hline & $t$ & 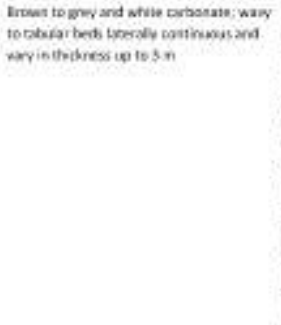 & 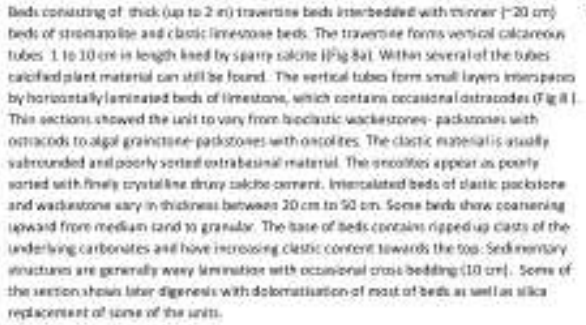 & Dittenate - ikh ipece condikent \\
\hline
\end{tabular}

This article is protected by copyright. All rights reserved. 


$\begin{array}{lll}\text { Interpretation-environment } & \text { Main Facies } & \text { Lithostratigraphy } \\ \text { Ignimbrites } & \text { V1 } & \text { Salar de Atacama Ignimbites (SdA Ignimbrites) } \\ \text { Medial Fluvial Fan } & \text { C1, S1 } & \text { Lower Vilama Gravels (LVG) } \\ \text { Carbonate-rich Lake } & \text { L } & \text { Vilama Carbonates (VC) } \\ \text { Distal- Alluvial Lacustrine } & \text { S1, M1, V1 } & \text { Vilama Minibasin Mudstones (VMM) } \\ \text { Distal Alluvial-Mudflat-lacustrine } & \text { S1, M2, V1 } & \text { Mid-Vilama Redbeds (MVR) } \\ \text { Distal Fluvial Fan } & \text { C2 } & \text { Upper Vilama Gravels (UVG) }\end{array}$
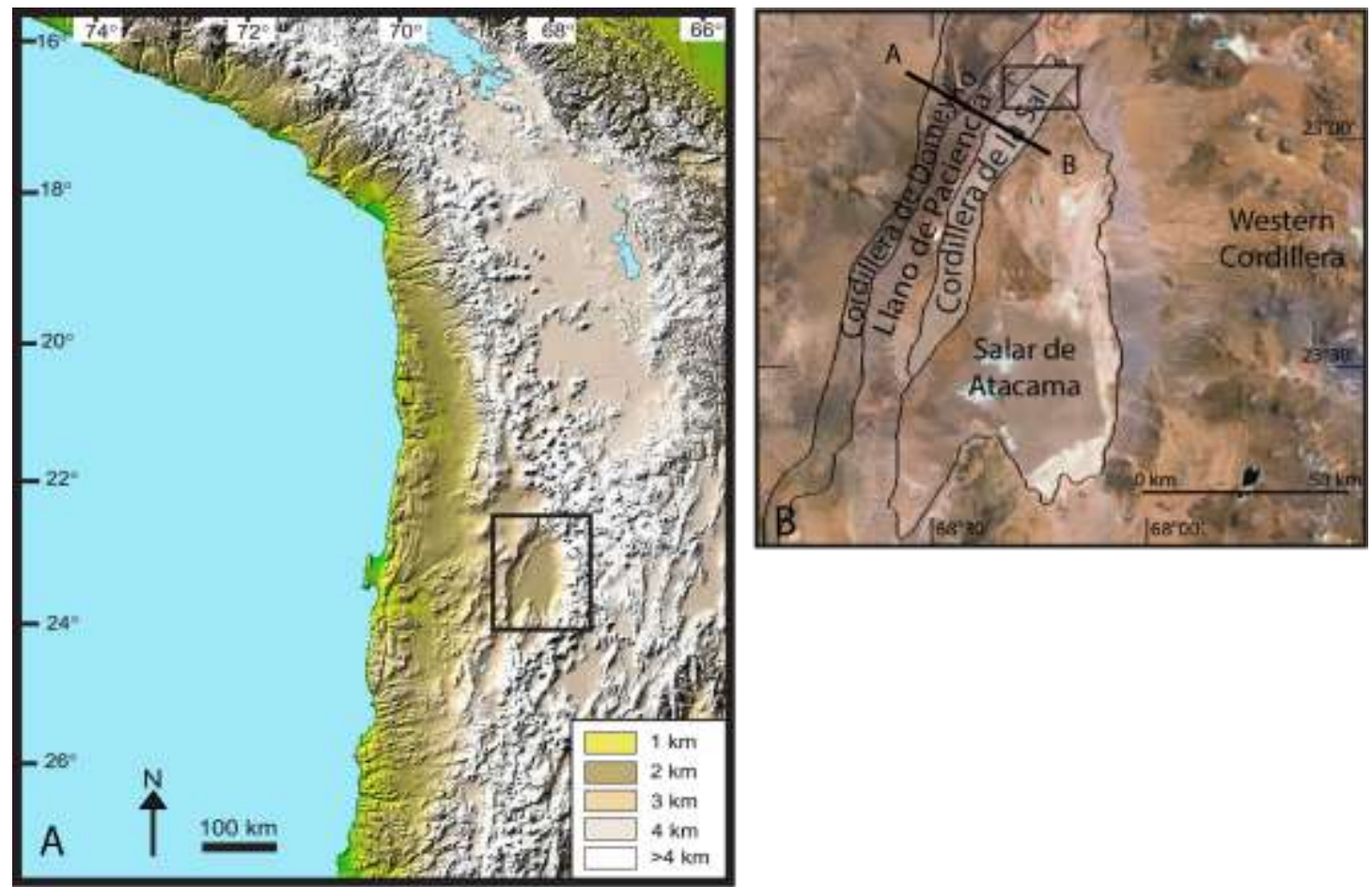

This article is protected by copyright. All rights reserved. 


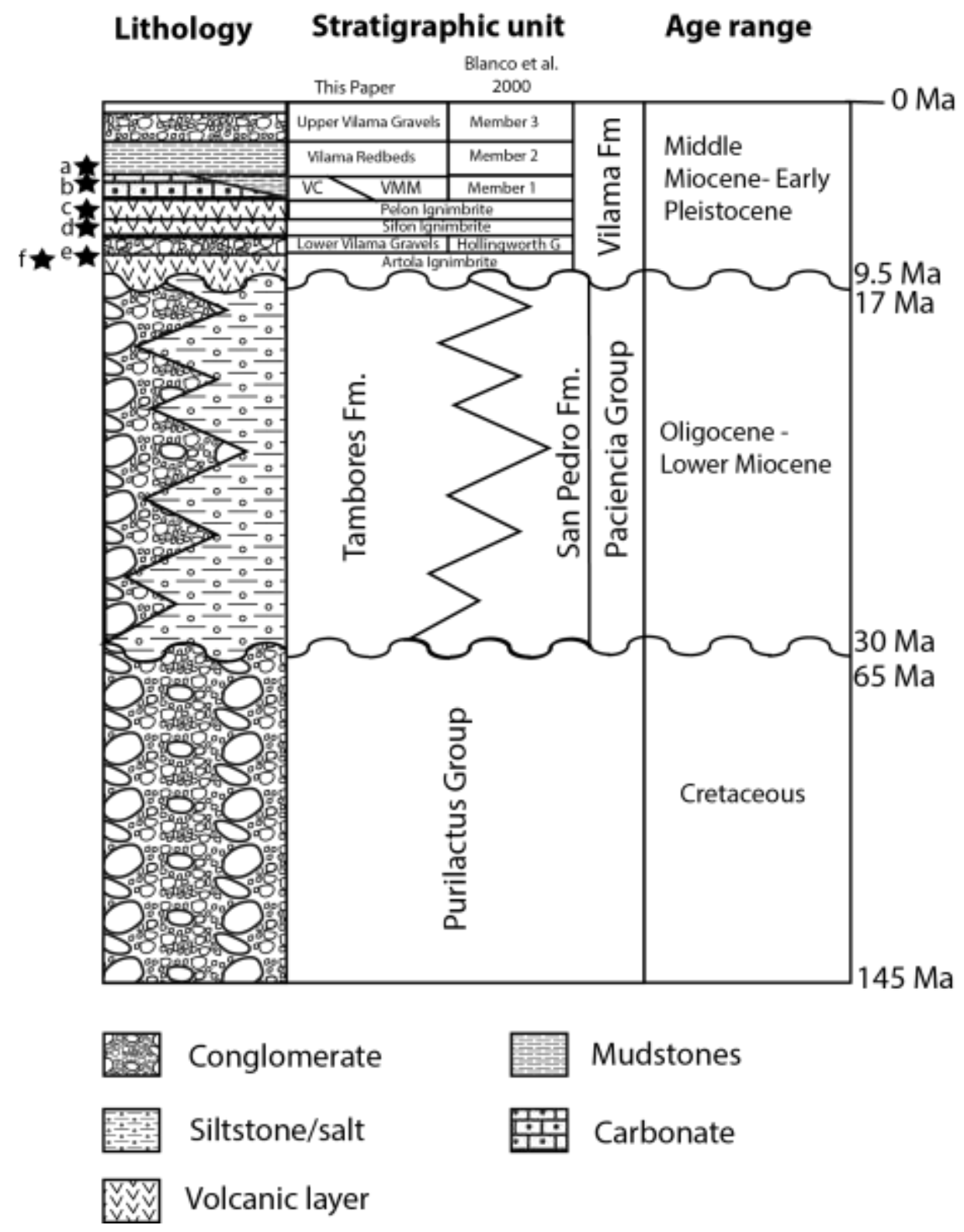

This article is protected by copyright. All rights reserved. 
A

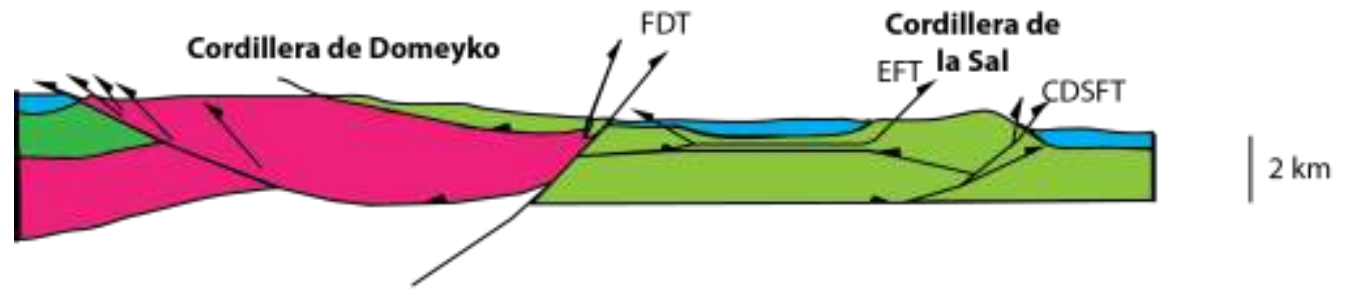

B

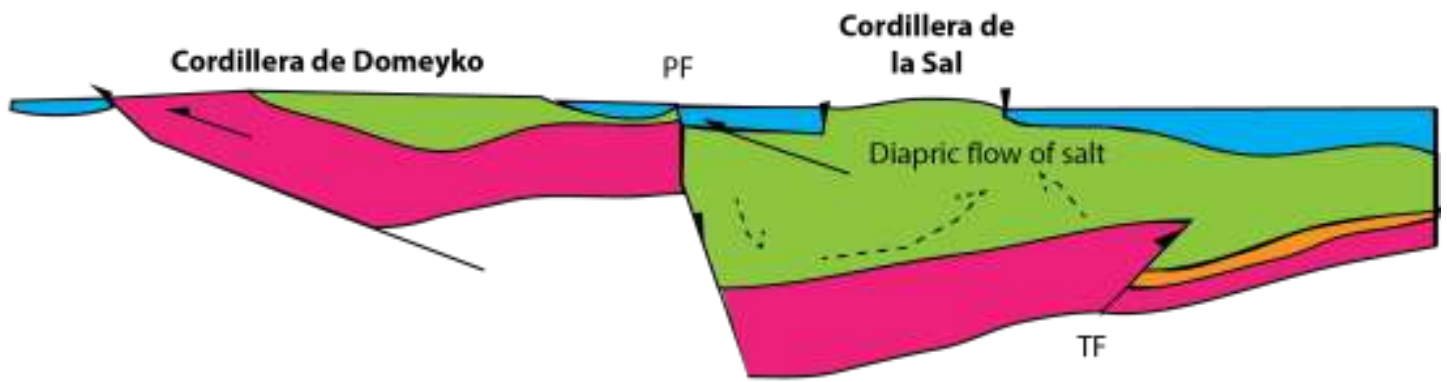

FDT - Frontal Domeyko Thrust EFT - Eastern Frontal Thrust

CDSFT - Cordillera de la Sal Frontal Thrust PF - Paciencia Normal Fault

Vilama Formation (Pliocene to Recent)

TF - Tulor Fault

Paciencia Group (Oligocene to Lower Miocene)

Lomas Amarilla Formation (Eocene)

Purilactis Group (Cretaceous)

This article is protected by copyright. All rights reserved. 


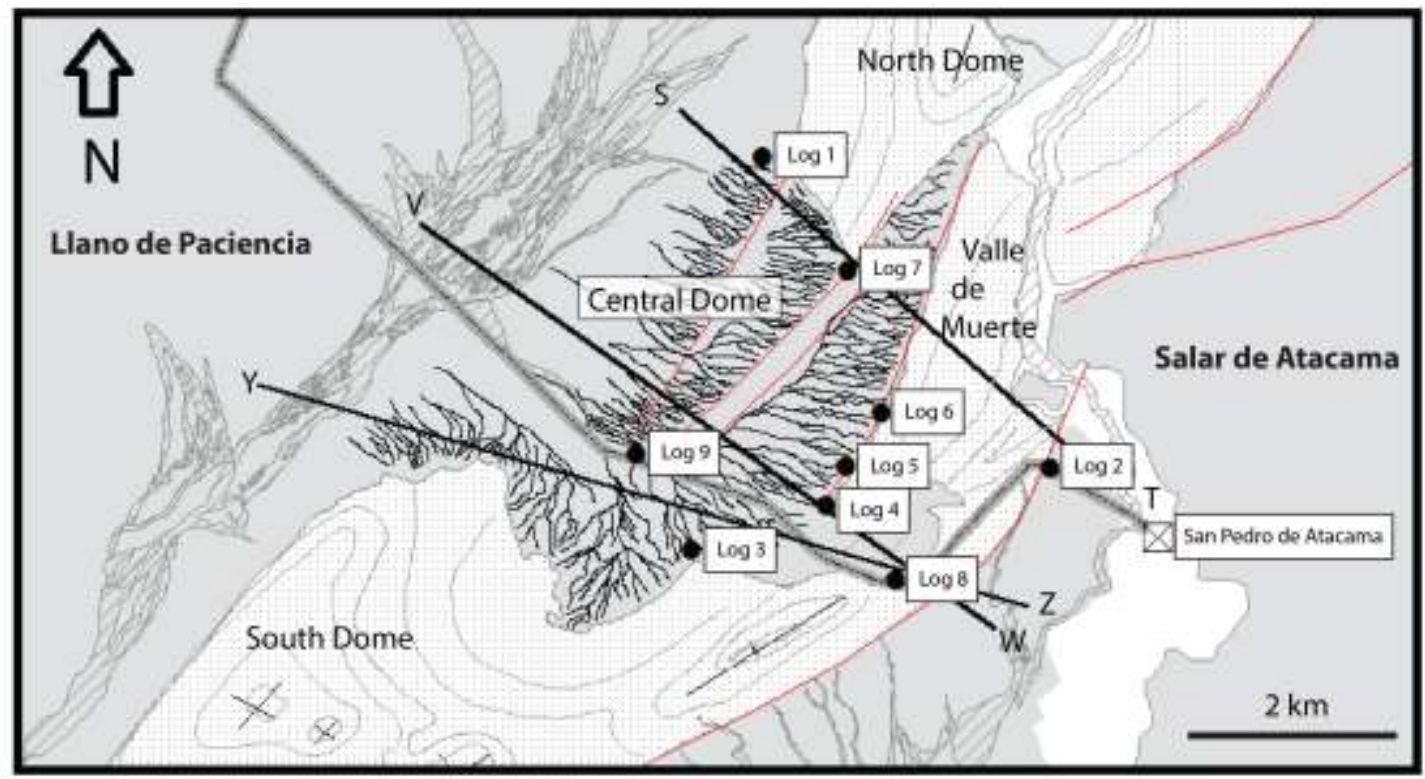

\begin{tabular}{|c|c|c|c|c|}
\hline Gy Conglomerate & Volcanic layer & $=$ & Partially laminated $\mathrm{ONO}$ & Travertine \\
\hline Pebble conglomerate & 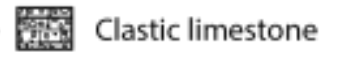 & $\equiv$ & Planar lamination & Stromatilite \\
\hline Sandstone & 監 Silt/sand carbonate & $\approx$ & Wavey lamination & Ostracods \\
\hline Siltstone & 監 Limestone & 2020 & Planar cross-stratification & \\
\hline Claystone & Volcanic silt & $\gamma$ & Trough cross-stratification & \\
\hline $\begin{array}{l}\text { Groundwater } \\
\text { Silcrete }\end{array}$ & Diatomite & & Climbing Ripples & \\
\hline
\end{tabular}

This article is protected by copyright. All rights reserved. 


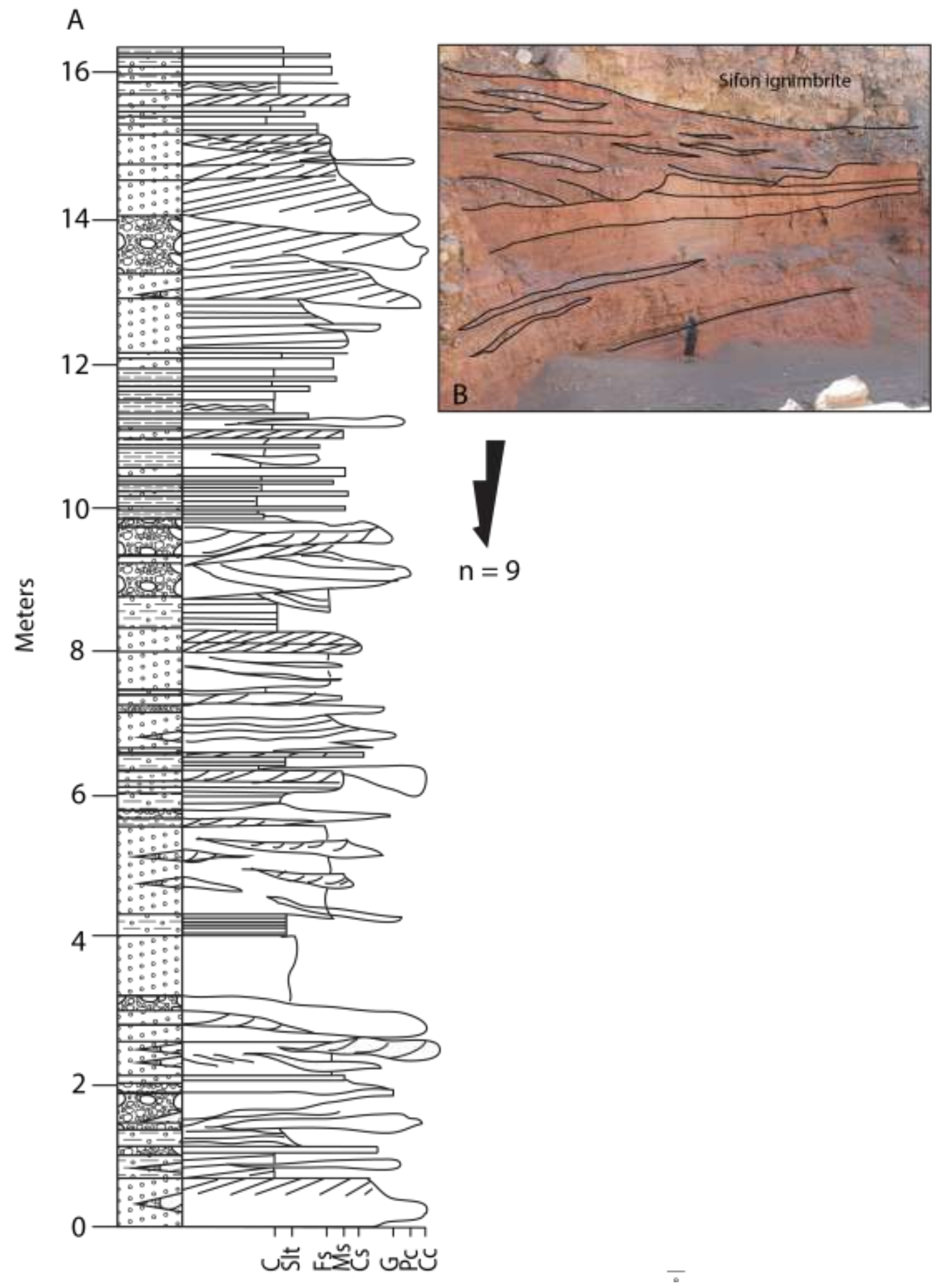

This article is protected by copyright. All rights reserved. 


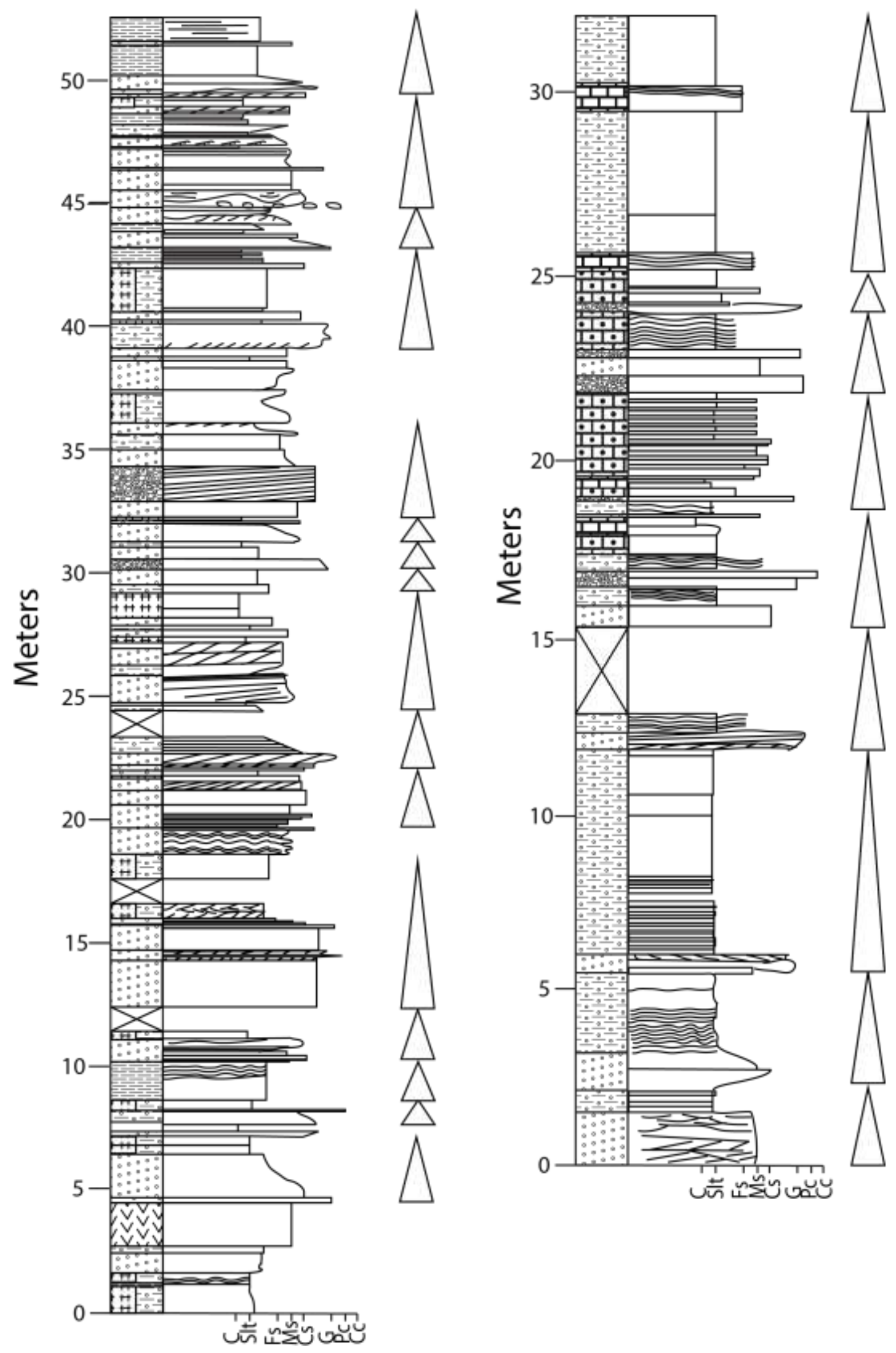

This article is protected by copyright. All rights reserved. 


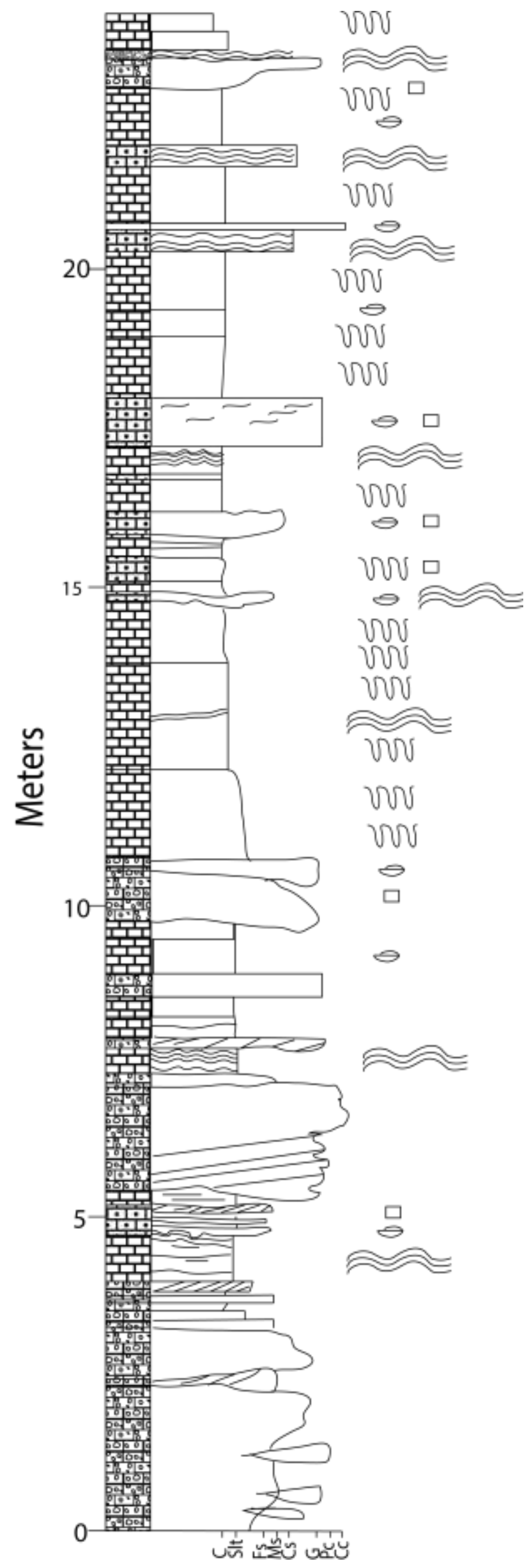

This article is protected by copyright. All rights reserved. 

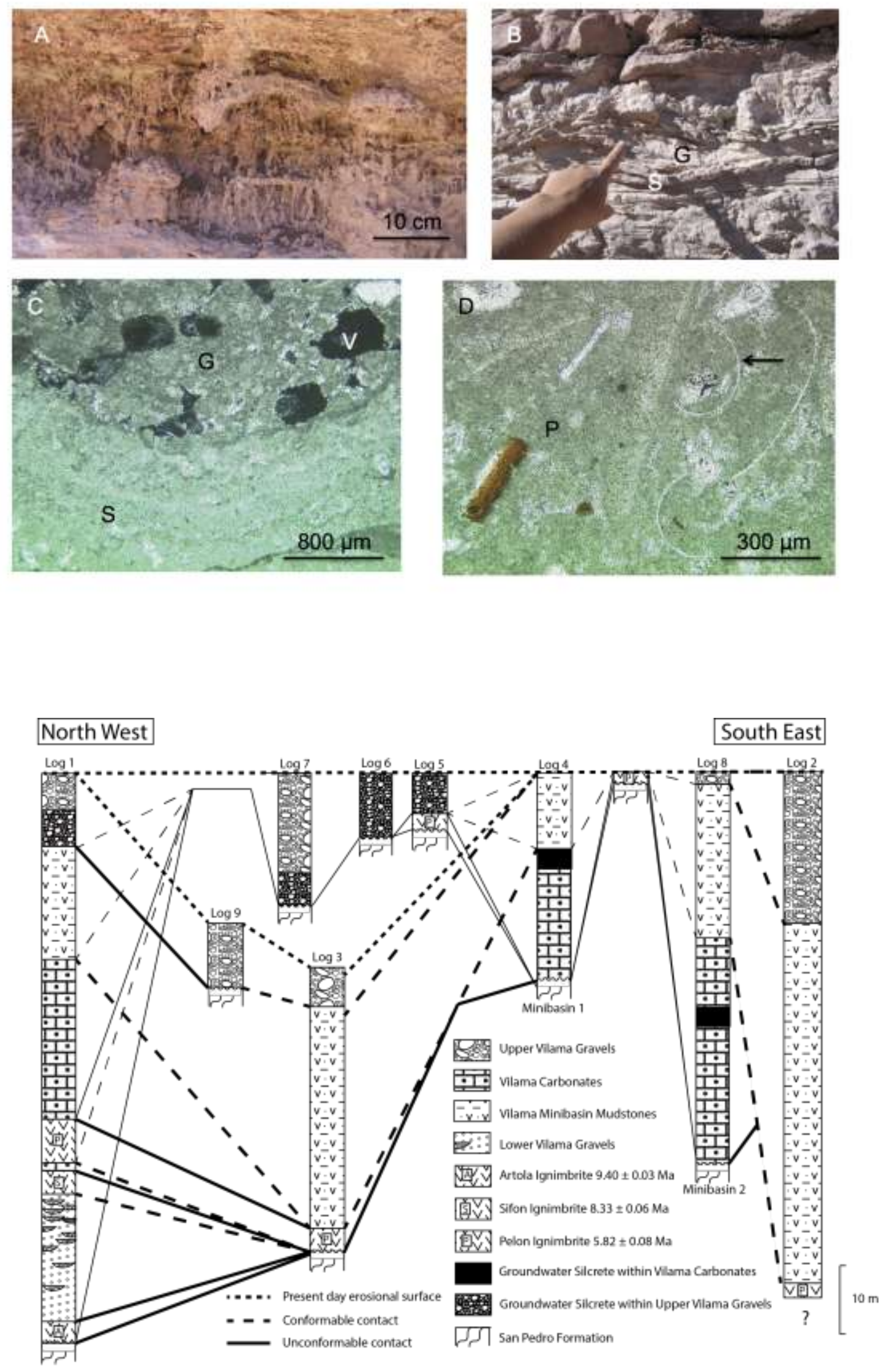

This article is protected by copyright. All rights reserved. 


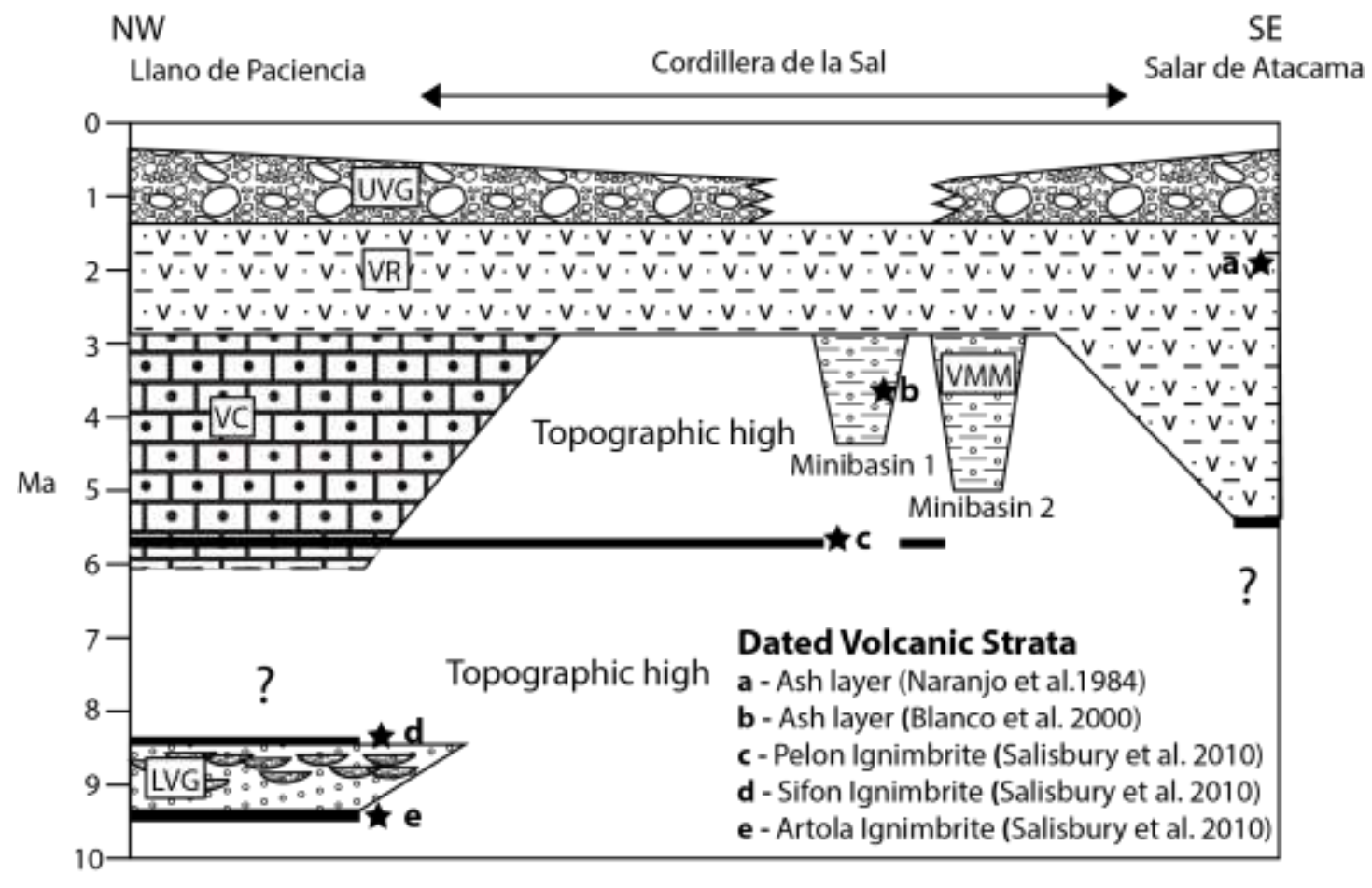

This article is protected by copyright. All rights reserved. 


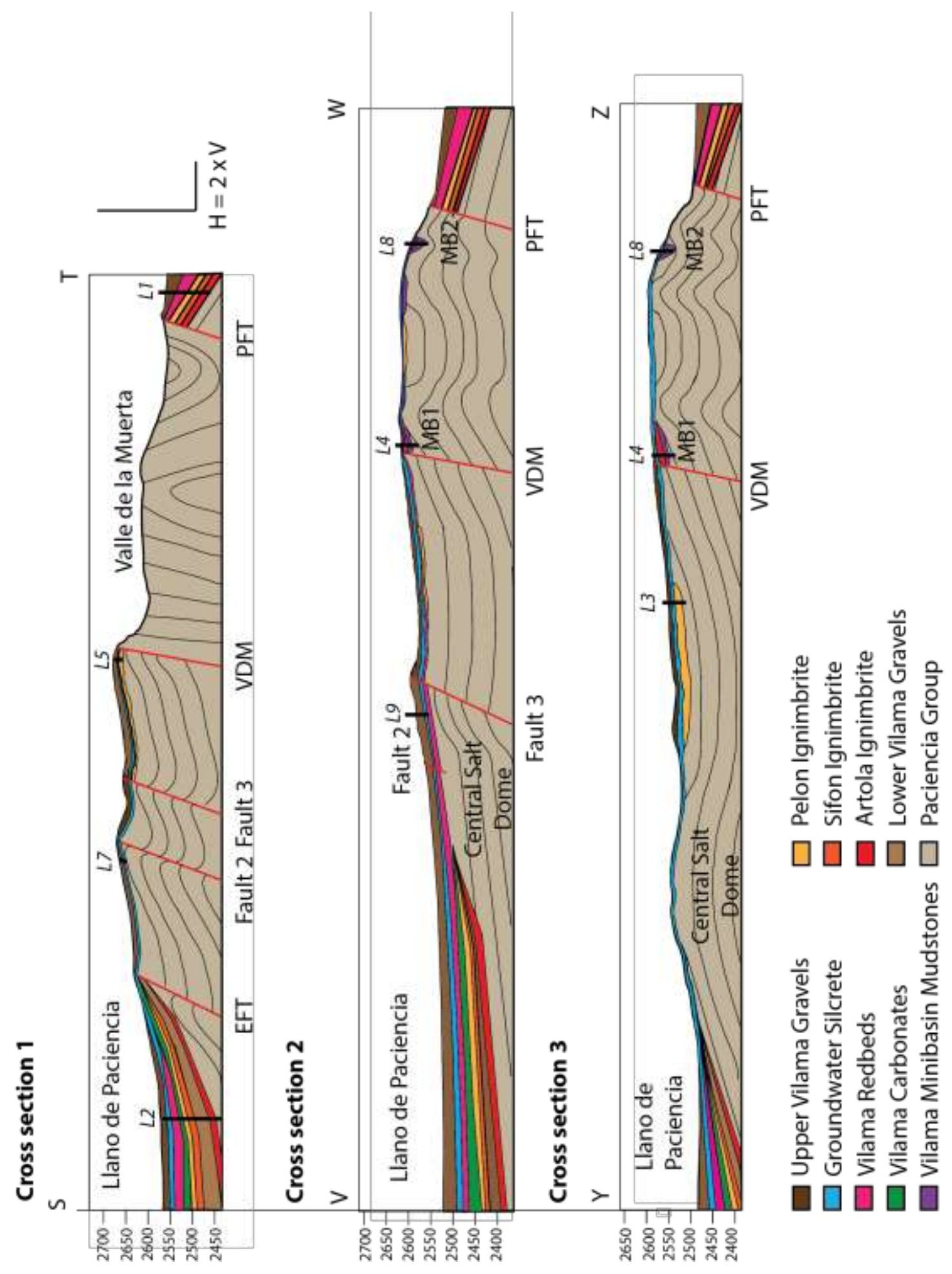

This article is protected by copyright. All rights reserved. 

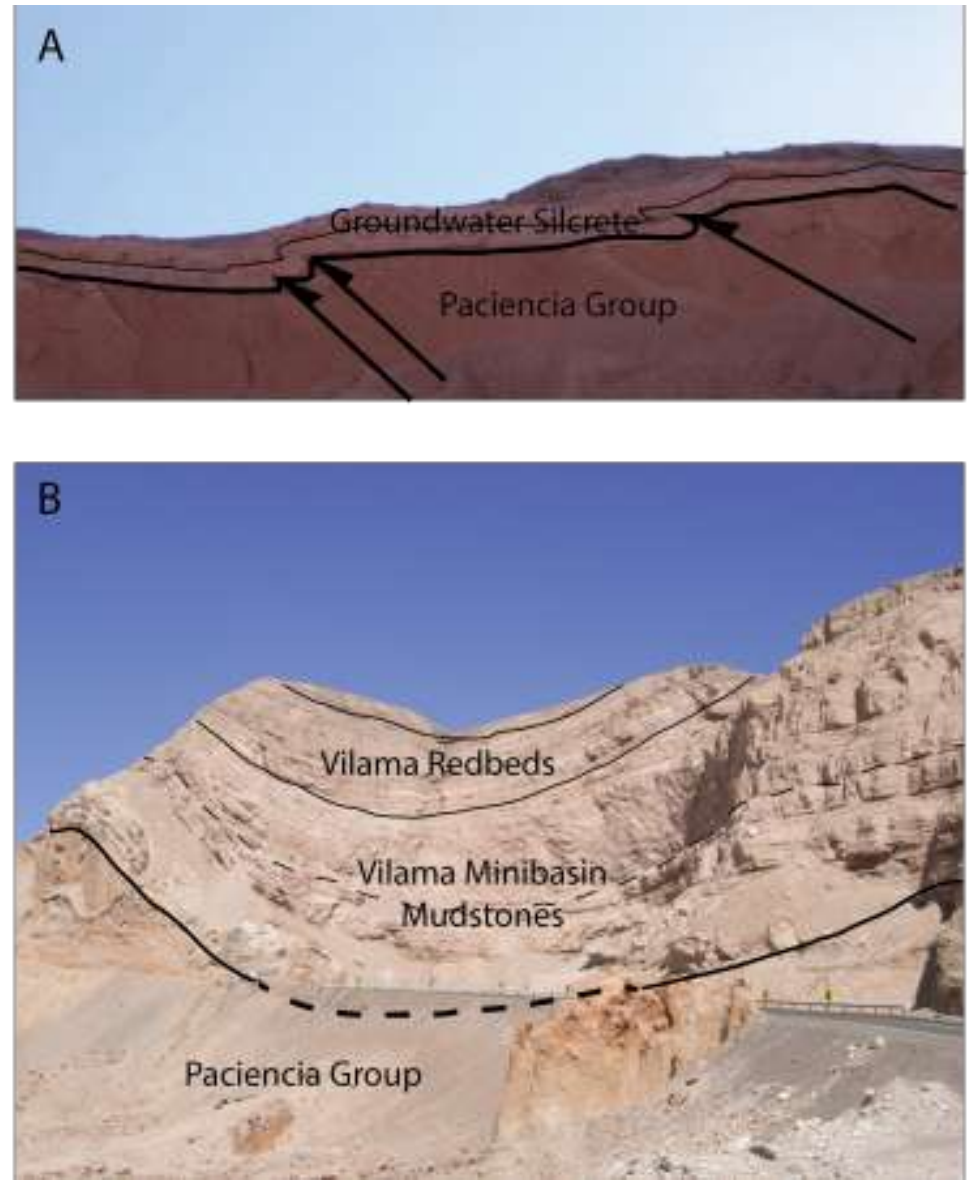

This article is protected by copyright. All rights reserved. 

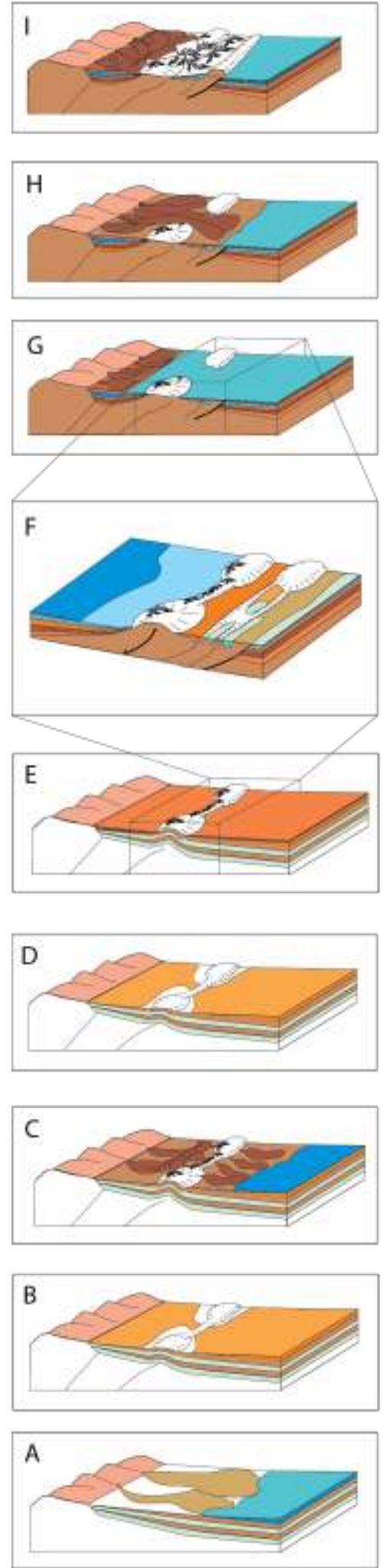

\section{Present Day}

Uplift along the Primary Frontal Thrust fault uplifts the eastern edge of the Cordillera de la Sal, tilting the Cordillera back to the west. Gravels are transported back into the Llano de Paciencia and then south.

\section{Upper Vilama Gravels}

The large lake dries up replaced by alluvial fan gravels which are channelised through the salt disolution feature from the Llano de Paciencia to the Salar de Atacama.

\section{Vilama Redbeds}

Decreased lake levels and salt body uplift leads to a wide spread deposition of the Vilama Redbeds across the Salar de Atacama, Cordillera de la Sal and Llano de Paciencia. A salt dissolution feature appears between the north and south dome.

\section{Vilama Carbonates and Minibasin Mudstones}

Shallow lake forms within the Llano de Paciencia. On the eastern edge of the Cordillera de la Sal small minibasins develop and are infilled with fluvial-lacustrine facies.

\section{Pelon Ignimbrite $(5.82 \pm 0.08 \mathrm{Ma})$}

Ignimbrite coats the subdivided topography covering the entire region close to the salt diapirs.

\section{Sifon Ignimbrite $(8.33 \pm 0.06 \mathrm{Ma})$}

Ignimbrite coat the region to the east and west of the salt diapirs and is preserved either side of the Cordillera de la Sal.

\section{Lower Vilama Gravels}

Cordillera de la Sal continues to uplift providing a barrier to eastward sediment transport from the Cordillera de Domeyko. Fluvial system is deflected to the north

\section{Artola Ignimbrite $(\mathbf{9 . 4 0} \pm \mathbf{0 . 0 3} \mathrm{Ma})$}

Ignimbrite coats the region showing an unconformable relationship with the underlying Paciencia Group. Initial uplift of Cordillera de la Sal with pinching out of Artola over the salt domes.

\section{Paciencia Group}

Alluvial fans from the Cordillera Domeyko flow across the Llano de Paciencia and interfinger with saline lake deposits

This article is protected by copyright. All rights reserved. 


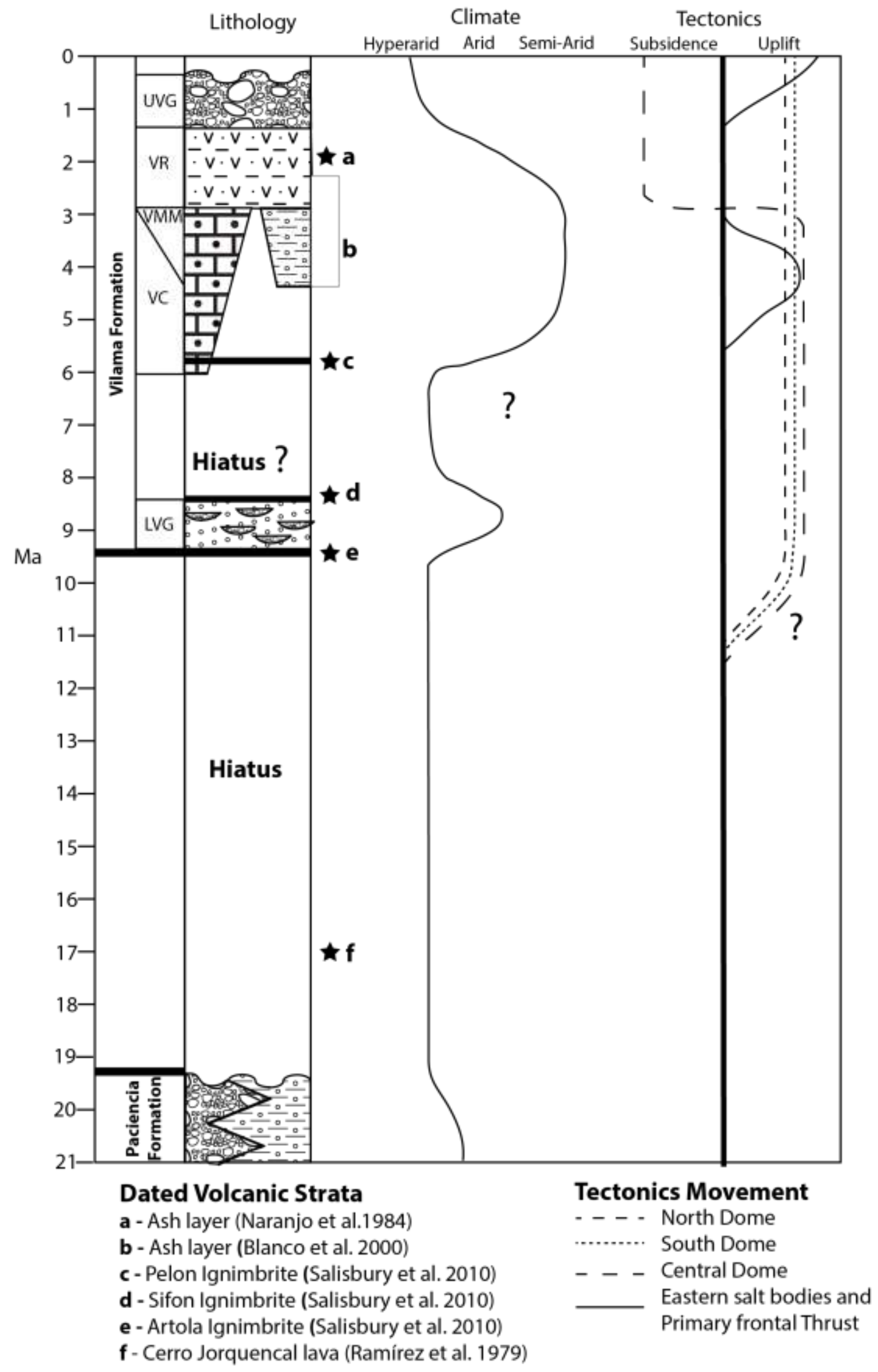

This article is protected by copyright. All rights reserved. 